\title{
REVIEW
}

\section{Molecular pathways disrupted by gestational diabetes mellitus}

\author{
Caitlyn Nguyen-Ngo 1,2,*, Nanthini Jayabalann',3,*, Carlos Salomon ${ }^{3,4}$ and Martha Lappas 1,2 \\ ${ }^{1}$ Mercy Perinatal Research Centre, Mercy Hospital for Women, Heidelberg, Victoria, Australia \\ 2Obstetrics, Nutrition and Endocrinology Group, Department of Obstetrics and Gynaecology, University of Melbourne, Victoria, Australia \\ 3Exosome Biology Laboratory, Centre for Clinical Diagnostics, The University of Queensland Centre for Clinical Research, Royal Brisbane and Women's \\ Hospital, The University of Queensland, Brisbane, Australia \\ ${ }^{4}$ Department of Clinical Biochemistry and Immunology, Faculty of Pharmacy, University of Concepción, Concepción, Chile
}

Correspondence should be addressed to M Lappas: mlappas@unimelb.edu.au

*(C Nguyen-Ngo and N Jayabalan contributed equally to this work)

\begin{abstract}
Gestational diabetes mellitus (GDM) imposes serious short- and long-term health problems for mother and baby. An effective therapeutic that can reduce the incidence of GDM and improve long-term maternal and fetal outcomes is a major research priority, crucially important for public health. A lack of knowledge about the underlying pathophysiology of GDM has hampered the development of such therapeutics. What we do know, however, is that maternal insulin resistance, low-grade inflammation and endothelial cell dysfunction are three central features of pregnancies complicated by GDM. Indeed, data generated over the past decade have implicated a number of candidate regulators of insulin resistance, inflammation and endothelial cell dysfunction in placenta, maternal adipose tissue and skeletal muscle. These include nuclear factor$\kappa B(N F-\kappa B)$, peroxisome proliferator-activated receptors (PPARs), sirtuins (SIRTs), 5' AMP-activated protein kinase (AMPK), glycogen synthase kinase 3 (GSK3), PI3K/mTOR, inflammasome and endoplasmic reticulum (ER) stress. In this review, the identification of these as key modulators of GDM will be discussed. The biochemical pathways involved in the formation of these may represent potential sites for intervention that may translate to therapeutic interventions to prevent the development of GDM.
\end{abstract} Key Words

Journal of Molecular Endocrinology (2019) 63, R51-R72

\section{Introduction}

Gestational diabetes mellitus (GDM) is defined as glucose intolerance of variable severity with first recognition during pregnancy (HAPO Study Cooperative Research Group et al. 2008). GDM is the most common pregnancy complication, affecting up to $20 \%$ of all pregnancies (Xiong et al. 2001, Ferrara 2007, Reece et al. 2009, Suntorn \& Panichkul 2015). The prevalence is greater amongst indigenous Australians (Ishak \& Petocz 2003) and in women whose native country is China or India compared to whose from a Caucasian background (Beischer et al. 1991).

GDM is a multifactorial disease. Risk factors include family history of type 2 diabetes and GDM (Solomon et al. 1997, Cedergren 2004, Setji et al. 2005), and having polycystic ovarian syndrome (PCOS) (Lo et al. 2006, Norman et al. 2007). Furthermore, the prevalence of GDM is growing with the obesity epidemic (Solomon et al. 1997, Kim et al. 2013b) and the older maternal age trend 
that is characterised in developed countries (Solomon et al. 1997, Wolf et al. 2004). Both maternal pre-pregnancy weight (Chu et al. 2007) and maternal weight gain during pregnancy have a strong correlation with GDM (Hedderson et al. 2010, Gibson et al. 2012). Therefore, unsurprisingly, eating a high-fat or low-fibre and highglycaemic index diet (Montonen et al. 2003, Zhang et al. 2006a) and having a sedentary lifestyle (Weissgerber et al. 2006) adds to the risk of GDM.

There are many short- and long-term complications associated to GDM for the mother and child (Dabelea et al. 2000). In the short term, GDM women are at a greater risk of hypertension induced by pregnancy, and even preeclampsia in severe cases (Xiong et al. 2001, HAPO Study Cooperative Research Group et al. 2008). Hyperglycaemia during late gestation is associated with macrosomia (or large-for-gestational age; greater than 90th percentile) (Langer et al. 2005). The Hyperglycemia Adverse Pregnancy Outcome (HAPO) Study indicated that even mild cases of hyperglycaemia increase the risk of macrosomia (HAPO Study Cooperative Research Group et al. 2008). Macrosomia is a surrogate risk for other complications, such as shoulder dystocia, induced birth and delivery by Caesarean section (Langer et al. 2005). Babies who are not macrosomic tend to have greater adiposity when adjusted for gestational age (Catalano et al . $2003 b$ ) which indicates metabolic dysfunction in utero. Other neonatal complications include hypoglycaemia, hyperbilirubinaemia, hypocalcaemia, and infant polycythaemia (Langer et al. 2005).

Long-term complications in both mother and baby include type 2 diabetes (Kim et al. 2002, Catalano et al. 2003a, Lee et al. 2007, Bellamy et al. 2009), obesity (Catalano et al. 2003a), cardiovascular disease (CVD) (Catalano et al. 2003a) and some cancers later in life (Perrin et al. 2007, 2008, Wu et al. 2012, Tong et al. 2014). Additionally, although fasting plasma glucose concentrations returns to the normal range (Ryan et al. 1985), the mother is more likely to experience recurrent GDM during the following pregnancy (Bottalico 2007). Depending on the population and the diagnostic criteria used, the risk of type 2 diabetes mellitus (T2DM) in women with GDM after 1 year can vary from 3 to $38 \%$ (Metzger et al. 1985, Lam et al. 1991, Lee et al. 2007). These health impacts of GDM present a significant challenge to finite healthcare resources. The current cost of caring for women with GDM is $34 \%$ greater than for healthy women during pregnancy or an estimated extra US $\$ 1.3$ billion per year (Gillespie et al. 2013). Exacerbating the problem are additional ongoing higher healthcare costs for mothers who had GDM, which average $20 \%$ more $2-5$ years after pregnancy (Gillespie et al. 2013). A better understanding of the pathophysiology of GDM is required in order to develop more effective intervention that can prevent GDM and thereby reduce its burden.

\section{Pathophysiology of GDM}

There are several distinct features of GDM pathophysiology including peripheral maternal insulin resistance, inflammation, and placental and endothelial dysfunction. These features will be discussed in depth in the following sections.

\section{Maternal insulin resistance}

During normal pregnancy, there is a progressive decline in insulin sensitivity, elevating the circulating levels of fatty acids and glucose to meet the increased energy demands of the developing fetus (Binder et al. 2015, Law \& Zhang 2017). Progressive insulin resistance can occur at the start of the second trimester of pregnancy, and by the third trimester, glucose utilisation is demonstrated to decline 40-60\% depending on BMI (Catalano et al. 1991, Sivan et al. 1997). Longitudinal studies have indicated that the maternal depots reduce fat accrual is insensitive to changes in circulating leptin levels (Highman et al. 1998), while lipid and glucose metabolism is hindered during late pregnancy (Herrera 2000). Pregnancy also causes hypertriglyceridaemia since plasma-free fatty acids become the maternal supplementary energy source, particularly during late pregnancy (Silliman et al. 1994, Sattar et al. 1997, Hubel et al. 1998, Brizzi et al. 1999). Nonetheless, euglycaemia is achieved as pancreatic $\beta$-cells compensate by hypertrophy and hyperplasia to produce more insulin (Assche et al. 1978, Ryan et al. 1985). The supply of glucose and amino acids are prioritised for the growing fetus (Barbour et al. 2004). However, in GDM, $\beta$-cell function is reduced by $30-70 \%$, indicating that $\beta$-cells are unable to compensate for the increase in insulin resistance, resulting in the development of GDM (Xiang et al. 1999, Lain \& Catalano 2007, Baeyens et al. 2016). Insulin resistance associated with GDM is further exacerbated by approximately $56 \%$ due to defective insulin signalling in adipose tissue and skeletal muscle (Catalano et al. 1991, Colomiere et al. 2009). GDM patients exhibit lower protein expression and tyrosine phosphorylation of the insulin receptor (IR)- $\beta$ and insulin receptor substrate (IRS)-1 in adipose tissue and skeletal muscle compared to pregnant women with normal 
glucose tolerance (NGT) (Shao et al. 2002, Colomiere et al. 2009). However, women with GDM also display a greater proportion of serine phosphorylated IRS-1 (Shao et al. 2002, Barbour et al. 2006). Phosphorylation of IRS- 1 at the serine residue impairs its ability to bind to phosphoinositide 3 kinase (PI3K) (Cheatham et al. 1994, Aguirre et al. 2002) and inhibits the tyrosine kinase activity of IR- $\beta$ (Aguirre et al. 2002). Transgenic mouse studies imply that IRS- 1 serine phosphorylation may play a role in the development of insulin resistance (Morino et al. 2008). The exact mechanism responsible for insulin resistance in pregnancy is yet to be fully elucidated. Nonetheless, the temporal changes of pregnancy hormones and cytokines are thought to be related to the shift in metabolism. The increase in progesterone level was proposed to have an impact on maternal carbohydrate metabolism (Branisteanu \& Mathieu 2003). Wada et al. have demonstrated that progesterone can inhibit glucose uptake in 3T3-L1 adipocytes by reducing the expression of IRS-1 which suppresses the PI-3K mediated pathway (Wada et al. 2010). Furthermore, knockout of the progesterone receptors in mice improved glucose tolerance as there was greater number of $\beta$-cells (Picard et al. 2002). Similarly, human placental growth hormone can also trigger insulin resistance in skeletal muscle (Barbour et al. 2004). However, Catalano et al. (2002) reported no differences in plasma progesterone levels in GDM women compared to NGT pregnant women. On the other hand, discrepancies exist on human placental lactogen profile in GDM pregnancies where the human placental lactogen level was reported to be normal (Beck et al. 1965, Catalano et al. 2002, Barbour 2003, Endo et al. 2006), higher (Saxena et al. 1969, Singer 1970, Selenkow et al. 1971) or lower (Spellacy et al. 1971) compared to normal pregnant controls. Emerging evidence, however, now implicates a more important role for pro-inflammatory cytokines released from placenta and maternal adipose tissue in inducing insulin resistance. The role of inflammation in GDM pathophysiology will be discussed further below.

\section{Inflammation}

Increasing 'omics'-based evidence suggest that GDM elicits major changes in the placental gene profile (Radaelli et al. 2003, 2009, Enquobahrie et al. 2009, Zhao et al. 2011b, Binder et al. 2015). Of note, these studies most commonly identify enrichment for inflammatory pathways (both markers and mediators of inflammation) in the GDM placenta. Results of previous studies indicate that moderate inflammation during pregnancy is correlated with insulin resistance and GDM (Kirwan et al. 2002, Wolf et al. 2004). Several excellent reviews further detail the role of inflammation in GDM pathophysiology (Vrachnis et al. 2012, Abell et al. 2015, Lekva et al. 2016). Increased secretion of pro-inflammatory cytokines have been noted to occur in early pregnancy, followed by insulin resistance in the third trimester, hence suggesting that proinflammatory cytokines and chemokines may be involved in the development of insulin resistance (Abell et al. 2015). Elevated circulating levels of pro-inflammatory cytokines TNF- $\alpha$ and IL- 6 , and reduced levels of anti-inflammatory cytokines IL-10 and IL-4 have been identified in GDM, regardless of BMI (Ategbo et al. 2006). Specifically, TNF- $\alpha$ has been shown to be associated with insulin resistance in human pregnancy (Kirwan et al. 2002), while nonpregnant mouse studies have demonstrated that TNF- $\alpha$ is involved in the development of insulin resistance (Uysal et al. 1997, 1998, Li et al. 2009). Together, these findings suggest that elevated expression of pro-inflammatory cytokines such as TNF- $\alpha$ during gestation may be a cause of insulin resistance associated with GDM.

Notably, in vitro studies have shown that maternal adipose tissue, maternal skeletal muscle and placenta may contribute to a differential inflammatory profile in GDM compared with NGT pregnancies. Adipose tissue is a complex active endocrine tissue that is thought to play key roles in GDM pathophysiology. Increased depth of adipose tissue has been found significantly correlated with risk of GDM, where adipocytes isolated from GDM pregnancies displayed increased cell size when compared to NGT adipocytes (Rojas-Rodriguez et al. 2015, De Souza et al. 2016). This larger adipocyte size was significantly correlated with increased serum glucose (Rojas-Rodriguez et al. 2015). Adipose tissue from GDM pregnancies also displayed reduced capillary density, and increased expression of markers of endothelial dysfunction, which may contribute to the altered physiology of the adipose tissue (Lappas 2014d, Rojas-Rodriguez et al. 2015). Adipose tissue is also known to differentially regulate the expression of adipokines and inflammatory markers. For example, adiponectin mRNA expression is reduced in both omental and subcutaneous adipose tissue (Ott et al. 2018), but leptin mRNA expression and protein secretion are increased in both adipose tissues from GDM pregnancies compared with NGT pregnancies (Lappas et al. 2005a, Lappas 2014b, Tsiotra et al. 2018). The increase in leptin expression may also be contributing to the abnormal expression and regulation of fatty acid uptake and transport in GDM pregnancies (Lappas 2014b). Finally, adipose tissue from GDM pregnancies exhibit increased 
gene expression of IL- 6 and IL-8 in GDM pregnancies, compared to NGT pregnancies (Kleiblova et al. 2010, Kuzmicki et al. 2012, Bari et al. 2014).

Likewise, in skeletal muscle, TNF- $\alpha$ is known to promote expression and secretion of other cytokines and chemokines IL-6, IL-8 and MCP-1 in skeletal muscle (Nagaraju et al. 1998, Lappas et al. 2004). These proinflammatory mediators may also interfere with the insulin signalling pathway, and thus, induce insulin resistance in the skeletal muscle (del Aguila et al. 1999, Rieusset et al. 2004).

The placenta has been widely demonstrated to be a source of inflammation. Several studies have found increased concentrations of leptin and upregulation of TNF- $\alpha$ signalling genes, as well as upregulated IL-1 receptor and IL-8 receptor genes in GDM placentas compared to NGT placentas (Radaelli et al. 2003, Lappas et al. 2005a, Enquobahrie et al. 2009, Magee et al. 2014). In addition, GDM pregnancies exhibit increased serum macrophagic marker sCD163 in early pregnancy (Ueland et al. 2019), and increased placental expression of macrophagic markers CD14+ and CD68+ at term, accompanied by enhanced mRNA expression of TNF- $\alpha$ and IL-6 (Yu et al. 2013, Mrizak et al. 2014). Importantly, these pro-inflammatory cytokines are known to promote the expression and secretion of the chemokines IL-8 and MCP-1 in the placenta (Lappas et al. 2004, 2006).

\section{Placental dysfunction}

The placenta is the key site of nutrient transfer from the mother to the fetus. Without significant fetal gluconeogenesis (Kalhan \& Parimi 2000), the fetus relies on obtaining glucose from maternal circulation via the placenta. To accommodate this, the maternal state becomes insulin resistant and reduces glucose uptake by maternal insulin target tissues, instead allowing placental uptake and transfer of glucose to the fetus, mediated by glucose transporters (GLUTs). In the placenta, the GLUT-1 isoform is localised to the synctiotrophoblast and is thought to be involved in glucose uptake from the maternal circulation (Illsley 2000). On the other hand, the GLUT-3 isoform is localised to placental endothelial cells and thought to be involved in glucose transfer to the fetus (Illsley 2000). GLUT-1 acts as the rate-limiting step for glucose transfer and the changes in the density of GLUT-1 can potentially affect the rate of transfer (Illsley 2000). The basal membrane (glucose delivery) expresses greater number of GLUT-1 compared to microvillous membrane (glucose uptake) demonstrating the maternal to fetal transfer (Jansson et al. 1993). GDM is associated with altered placental glucose metabolism (Osmond et al. 2001, Jansson \& Powell 2006) and altered amino acid transport (Jansson et al. 2002) and lipid (Segura et al. 2017) concentrations. Consequentially, GDM trophoblasts exhibit a two-fold increase in GLUT-1 expression and $40 \%$ increase in glucose uptake in the trophoblast basal membrane (Gaither et al. 1999). These observed changes in GLUT-1 expression may potentially increase glucose uptake from the maternal circulation into the basal membrane. On the other hand, the mRNA expression of GLUT-3 was increased in GDM placenta (Dekker Nitert et al. 2014). Given the higher affinity of GLUT-3 for glucose (Hay 2006) and its localisation in endothelial cells, the increased expression of GLUT-3 in GDM may play a role in the transmission of glucose to fetus after the trans-syncytial transport contributing for fetal overgrowth.

This observed increase in trophoblast glucose uptake may contribute to further inflammation in the placenta, as hyperglycaemic conditions have been noted to stimulate a pro-inflammatory response in human trophoblasts (Heim et al. 2018). Metainflammation which is triggered by metabolites causes development of systemic insulin resistance (Gregor \& Hotamisligil 2011). In line with this, increased circulating levels of inflammatory molecules in GDM pregnancies is known (Hauguel-de Mouzon \& Guerre-Millo 2006) and changes in circulating inflammatory profile can enhance insulin resistance in mothers which subsequently influences placental nutrient transport. Evidently, the overexpression of placental TNF- $\alpha$ is associated with increased fetal adiposity (Radaelli et al. 2003). Besides fetal adiposity, increased glucose transfer to the fetus causes fetal hyperglycaemia and fetal hyperinsulinaemia (Díaz et al. 2017). Since the basal membrane GLUT-1 expression is regulated by insulinlike growth factor 1 (IGF1) (Baumann et al. 2014), fetal hyperglycaemia may induce the secretion of fetal IGF1 which can regulate the expression of basal membrane GLUT-1 in a feedback loop manner. This will maintain the increase in transplacental glucose transport and consequently excessive fetal weight gain or macrosomia.

Insulin receptor expression is also present in the placenta, and its distribution varies depending on gestational age. While the insulin receptor can be found at the microvillous membrane in early pregnancy, term insulin receptor expression is primarily localised at the endothelium (Desoye et al. 1994, 1997). These spatiotemporal changes suggest a role for maternal and fetal 
insulin in regulating placental function at different stage of pregnancies. The binding of insulin to insulin receptor activates the autophosphorylation on specific cytoplasmic tyrosine residues, which ensues downstream signalling (Pessin \& Saltiel 2000). Although the insulin receptor is not implicated in placental glucose transport, placental insulin signalling may instead contribute to lipid metabolism (Ruiz-Palacios et al. 2017). Examination of GDM placenta displayed reduced expression of insulin receptor together with reduced phosphorylation of its downstream molecule, Akt (Li et al. 2016). However, limited data are available on the consequences of altered placental insulin signalling on fetal outcome.

Other biochemical changes in the placenta also contribute to the development of GDM placenta including inflammation (as discussed in the previous section), increased placental oxidative stress (Lappas et al. 2011a), mitochondrial damage (Muralimanoharan et al. 2016) and ER stress (Yung et al. 2016). Several anatomical changes to the placenta, including significantly lower fetal-to-placental weight ratios (Taricco et al. 2003) and abnormal placental vascularisation (Suranyi et al. 2013), are also associated with GDM pathophysiology.

Leptin has been found to be overexpressed along with its receptor in GDM placenta (Perez-Perez et al. 2013) and has been demonstrated to exert anti-apoptotic effects on human trophoblast cells (Magarinos et al. 2007, PerezPerez et al. 2008). Thus, hyperleptinaemia in GDM may drive placental overgrowth by suppressing trophoblast apoptosis (Kautzky-Willer et al. 2001). Indeed, higher placental weight has been significantly associated with lower trophoblast apoptosis in GDM, thereby increasing the surface area available for nutrient transfer (Magee et al. 2014). Altogether, these trophoblast abnormalities may compromise placental function and contribute towards intrauterine fetal programming for metabolic disease later in life (Mele et al. 2014).

\section{Endothelial cell dysfunction}

Endothelial dysfunction is a state of imbalance between vasoconstriction and vasodilatation, predisposing patients to atherosclerosis and CVD - the principal complications of T2DM. Normal pregnancy is characterised by vasodilation, which reduces peripheral vascular resistance and enables an increase in uteroplacental blood flow. In GDM, however, endothelial function is impaired in the arteries that control blood flow to the placenta (uterine arteries), as well as those involved in controlling systemic vascular resistance (mesenteric arteries) (Knock et al. 1997,
Chirayath et al. 2010, Mrizak et al. 2013). Despite this, abnormal uterine blood flow has not been evidenced to affect glucose transfer to the fetus (Palacín et al. 1985). Instead, endothelial dysfunction during GDM pregnancy may be associated with impaired cardiometabolism postpartum (Göbl et al. 2014). The GDM placenta exhibits significant increases in key markers of endothelial dysfunction, such as endothelial-derived reactive oxygen and nitrative-derived species (Casanello et al. 2007, Westermeier et al. 2009). Markers of endothelial cell dysfunction, such as the cell adhesion molecules, vascular cell adhesion protein 1 (VCAM)-1 and intercellular adhesion molecule (ICAM)- 1 , are increased in omental adipose tissue with maternal obesity and GDM (Lappas 2014d), while circulating VCAM-1 and ICAM-1 are increased with GDM (Mordwinkin et al. 2013). Notably, alterations in endothelial dysfunction are related to inflammatory status (Mrizak et al. 2013, Di Fulvio et al. 2014, Lappas 2014d).

\section{Molecular pathways disrupted by GDM}

Extensive literature exists documenting the clinical consequences of GDM for the mother and fetus; however, much less is known in the way of the molecular basis of GDM pathogenesis. Several key pathways implicated in the development of GDM are shared with T2DM pathophysiology; however, these pathways will only be discussed in the context of GDM.

\section{NF-кB signalling pathway}

The nuclear factor-kappa-light-chain-enhancer of activated B cells (NF-kB) signalling pathway is one of the major and central pathways involved in gene expression for immune and inflammatory responses (Baldwin 1996). NF- $\mathrm{kB}$ exists in an inactive dimeric form in the cytoplasm, bound by the inhibitory protein IкB- $\alpha$. Upon activation by stimuli such as pro-inflammatory cytokines and endotoxin, IKB kinases (IKKs) induce phosphorylation and degradation of IкB- $\alpha$, thus allowing the NF- $\mathrm{kB}$ dimer to rapidly translocate to the nucleus. There, co-factor recruitment allows the NF- $\mathrm{BB}$ dimer to bind with cisacting Rel-binding $(\mathrm{\kappa B})$ sites promoter regions of several genes involved in inflammation and/or insulin resistance, thus initiating gene transcription.

Given that inflammation plays a key role in inducing insulin resistance, the activation of the NF- $\mathrm{kB}$ pathway is implicated in diabetic pathophysiologies. For example, high-dose salicylate administration is known to inhibit 
the IKK- $\beta / N F-\kappa B$ pathway, and the related compound aspirin had been used in the late 1800s to treat diabetes and dramatically reduce hyperglycaemia (Hundal et al. 2002). At a molecular level, aspirin and salicylate administration was found to reduce insulin resistance by blocking IKK- $\beta$ activity, allowing normalised activation of key insulin signalling molecules in skeletal muscle (Kim et al. 2001, Yuan et al. 2001). Indeed, patients with T2DM treated with high-dose aspirin reported improved glucose metabolism, highlighting the critical role that NF-kB/IKK$\beta$ play in inducing insulin resistance (Hundal et al. 2002).

The importance of the NF- $\mathrm{kB}$ pathway extends to GDM - increased NF-kB mRNA has been reported in the GDM placenta (Feng et al. 2016). While its expression in adipose tissue or skeletal muscle of GDM pregnancies are yet to be assessed, NF- $\mathrm{kB}$ remains a key factor for the regulation of the inflammation in these tissues obtained from pregnant women at the time of term Caesarean section (Lappas et al. 2005b). It is also worth noting that GDM pregnancies exhibit increased levels of chorionic gonadotrophin (CG), a pro-inflammatory compound that impairs insulin signalling in adipocytes through the NF- $\mathrm{BB}$ pathway (Ma et al. 2015). Such evidence points to the theory that NF- $\mathrm{\kappa B}$ contributes to the development of GDM by promoting adipocyte inflammation and impairing insulin-related functions, such as glucose uptake.

\section{Toll-like receptors (TLRs)}

Toll-like receptors (TLRs) are key surface molecules responsible for recognising conserved components of pathogenic microorganisms known as pathogenassociated molecular patterns (PAMPs), thus playing an essential role in triggering an inflammatory innate immune response (Vasselon \& Detmers 2002). Engagement of TLRs by PAMPs triggers intracellular signalling pathways that culminate in the activation of a number of pro-inflammatory transcription factors including NF-кB (Barton \& Medzhitov 2003). TLRs however lack catalytic domains and are connected to the cell-signalling machinery via intracellular adaptor molecules including the myeloid differentiation factor 88 (MyD88) and TNFRassociated factor 6 (TRAF6) (Medzhitov et al. 1998, Muzio et al. 1998).

To date, ten functional TLRs (TLR1-10) have been identified in humans; TLR1, TLR2, TLR4, TLR5, TLR6, and TLR10 are found primarily on the cell surface, while TLR3, TLR7, TLR8, and TLR9 are expressed in intracellular endosomes. Human placenta expresses TLR1-10 (Nishimura \& Naito 2005, Patni et al. 2009) with studies showing that most TLRs are functionally active in human placenta (Tangeras et al. 2014). GDM is associated with increased expression of TLR4 mRNA (Mrizak et al. 2014, Feng et al. 2016) and MyD88 in the placenta (Feng et al. 2016). The cause of this increase in placenta is not known; however, saturated fatty acids (Yang et al. 2015) and oxidised cholesterol metabolites (oxysterols) (Aye et al. 2012) enhance TLR4-induced inflammation in human primary trophoblasts.

Interestingly, TLR2 mRNA expression is increased in PBMCs obtained from the pregnant women who were normoglycaemic at the time of sampling but later developed GDM (Kuzmicki et al. 2013). Further, elevated PBMC, TLR2 and TLR4 mRNA expression was evident in GDM in the second trimester; however, 4 weeks later, the difference was not significant, probably as a result of an increase in TLR expressions in the healthy pregnant women (Kuzmicki et al. 2013). On the other hand, another study reported that TLR4 mRNA expression was significantly higher in maternal monocytes of patients with GDM obtained after 37 weeks gestation (Xie et al. 2014). Additionally, there was a positive correlation between the TLR4 mRNA expression level in peripheral blood monocytes and serum TNF- $\alpha$ levels (Xie et al. 2014). It is not known what increases the expression of TLRs in PBMCs from women with GDM; however, high glucose (Dasu et al. 2008) and saturated fat (Ghanim et al. 2009, Deopurkar et al. 2010) have been shown to increase TLR expression in human monocytes.

\section{Nucleotide-binding oligomerisation domains (NODs)}

Nucleotide-binding oligomerisation domain-containing 1 and 2 (NOD1 and NOD2) are intracellular pattern recognition receptors involved in the sensing of numerous microbes or microbial components which have gained access to the cell's cytoplasm (Franchi et al. 2009). The activation of NOD1 or NOD2 promotes the activation of NF-kB-mediated pro-inflammatory gene expression (Fritz et al. 2006, Strober et al. 2006). NOD1 and NOD2 have been shown to play an important role in inflammation and insulin resistance (Winzer et al. 2004, Zhao et al. 2011a, Yi-Jun et al. 2012, Zhou et al. 2012, Purohit et al. 2013). We have recently shown that NOD1 (but not NOD2) expression in increased in both subcutaneous and omental adipose tissue obtained from women with GDM when compared to BMI-matched NGT women (Lappas 2014b). Furthermore, treatment of subcutaneous and omental adipose tissue from NGT and GDM pregnant women with the NOD1 ligand iE-DAP 
significantly increased the expression of a number of inflammatory markers. Specifically, there was an increase in the expression and secretion of the pro-inflammatory cytokine IL-6, the pro-inflammatory chemokine IL-8, COX-2 and subsequent prostaglandin production, the ECM remodelling/degrading enzyme MMP-9, and the gene expression and secretion of the adhesion molecules ICAM-1 and VCAM-1. These effects of NOD1 appear to be mediated via the pro-inflammatory transcription factor NF-kB, as BAY 11-7082 ameliorated iE-DAPinduced inflammatory proteins. This study demonstrates that the NOD1 ligand iE-DAP significantly inhibits the insulin signalling pathway in omental adipose tissue from pregnant women, as evidenced by decreased phosphorylated IRS-1, GLUT-4 expression and glucose uptake. Together, these results indicate that NOD1 plays an important role in adipose tissue inflammation and insulin resistance that is evident in women with GDM.

\section{Peroxisome proliferator-activated receptors}

Peroxisome proliferator-activated receptors (PPARs) are ligand-activated transcription factors that heterodimerise with retinoid X receptor (RXR) and bind to peroxisome proliferator response elements (PPRE) in promoters of target genes (Ganss 2017). PPARs (PPAR $\alpha$, PPAR $\beta / \delta$, PPAR $\gamma$ ) regulate the expression of genes involved in inflammation, adipogenesis, oxidative stress, insulin signalling and glucose metabolism (McCarthy et al. 2013, Wójcik et al. 2015). PPAR $\gamma$ expression is lower in maternal adipose tissue, placenta and placental cells (i.e. syncytiotrophoblasts and extravillous trophoblasts) from women with GDM (Catalano et al. 2002, Arck et al. 2010, Holdsworth-Carson et al. 2010, Knabl et al. 2014). Further, placental levels of the natural anti-inflammatory $\operatorname{PPAR} \gamma$ agonist, 15-deoxydelta12,14-prostaglandin $\mathrm{J}_{2}\left(15 \mathrm{dPGJ}_{2}\right)$ are lower in women with GDM (Jawerbaum et al. 2004). In adipocytes, PPAR $\gamma$ signalling promotes blood glucose clearance by enhancing glucose uptake; thus, downregulated PPAR $\gamma$ expression in GDM may exacerbate glucose intolerance (Lendvai et al. 2016). Decreased expression of PPAR $\alpha$ and RXR $\alpha$ have also been identified in placentas from women with GDM (Holdsworth-Carson et al. 2010). The roles of PPAR $\alpha$ and RXRo in GDM are not known.

Although it is unclear if dysregulated PPAR expression is a cause or a consequence of GDM, PPARs may be potential therapeutic targets for the prevention or treatment of GDM. Indeed, PPAR $\gamma$ ligands such as thiazolidinediones (TZDs), which are synthetic agonists, are used in patients with T2DM to improve insulin sensitivity and glucose tolerance (Knabl et al. 2014, Ganss 2017). Likewise, resveratrol, a natural PPAR $\gamma$ ligand, decreases inflammation in human placenta and adipose tissue obtained from pregnant women and improves skeletal muscle insulin resistance in vitro (Tran et al. 2017). Moreover, animal studies have shown that resveratrol has beneficial effects on maternal glucose metabolism and insulin sensitivity (Roberts et al. 2014).

\section{Sirtuins}

In mammals, there are seven sirtuins (SIRT1-7) that differ in tissue distribution, subcellular localisation and substrate specificity (Michishita et al. 2005). They are classified accordingly to their amino acid sequences: class I (SIRT1-3), class II (SIRT4), class III (SIRT5) and class IV (SIRT6 and 7). SIRTs possess either $\mathrm{NAD}^{+}$-dependent histone deacetylase (SIRT1, 2, 3, and 5) or monoribosyltransferase (SIRT4 and 6) activity that contribute the transcription of certain genes in response stress stimuli or ageing. For the purpose of this review we will discuss the role of SIRT1, 3 and 6 in regulating inflammation and metabolic dysfunction.

\section{SIRT1}

SIRT1 is involved in dampening the inflammatory response, regulating the ageing process, cell death/ survival, metabolism, stress resistance and endocrine signalling (Michan \& Sinclair 2007). SIRT1 has been shown to directly interact with the p65 NF-кB subunit RELA and inhibits NF-kB transcriptional activity by the deacetylation of RELA at lysine residue Lys310 (Chen et al. 2005, Rajendrasozhan et al. 2008). Other studies have shown SIRT1 to regulate other transcription factors such as inhibiting the pro-inflammatory FOXO protein (Motta et al. 2004) and upregulates the activity of the antiinflammatory transcription factor PPAR (Purushotham et al. 2009).

There are, however, limited studies on the role of SIRT1 and GDM. Nevertheless, the available data suggest that SIRT1 may play a role in regulating inflammation and glucose metabolism in human placenta. Our preliminary data show that SIRT1 is expressed in human placenta and is significantly downregulated in placentas from pregnancies complicated with GDM (Lappas \& Liong unpublished observation). It is not known what causes the decrease in placental SIRT1 expression; however, bacterial endotoxin LPS (Lappas et al. 2011b), the pro-inflammatory cytokines TNF- $\alpha$ and IL-1 $\beta$ (Lappas et al. 2011b) and oxidative stress 
(Lappas et al. 2012) have all been shown to decrease SIRT1 expression in human placenta. Activation of SIRT1 by resveratrol, a phytophenol compound present in plants, red grapes, peanuts, vegetables, berries, beverages, and herbal medicines (Sanders et al. 2000, Burns et al. 2002), and the synthetic SIRT1 activator SRT1720, significantly suppressed LPS-induced release of pro-inflammatory cytokines and prostaglandins in human placenta (Lappas et al. 2011b). Furthermore, SIRT1 is involved in placental glucose uptake by regulating the transcription of GLUT-1 (Lappas et al. 2012).

Interestingly, women with GDM have elevated leukocyte SIRT1 mRNA compared to women with normal glucose tolerance (Anna Turek et al. 2014, Wojcik et al. 2014). Given the anti-inflammatory function of SIRT1, this increase in SIRT1 expression may be the result of a compensatory mechanism in response to the heightened inflammatory state associated with GDM. On the other hand, reduced SIRT1 expression and activity in fetal endothelial colony-forming cells (ECFCs) and human umbilical vein endothelial cells (HUVECs) were found in pregnancies complicated by GDM (Lappas 2012, Gui et al. 2016). This reduction of SIRTs in fetal cells may potentially link the development of long-term cardiovascular complications in offspring of GDM pregnancies.

Whether specific SIRT1 activators can prevent the development of GDM in vivo is unknown. However, of promise, a recent study found resveratrol to alleviate insulin resistance and improve glucose metabolism and fetal outcomes complicated by GDM in a mouse model (Yao et al. 2015). GDM mice treated with resveratrol had increased activation of the adenosine monophosphate (AMP)-activated protein kinase (AMPK) in maternal liver as well as in their offspring. There is an extensive body of evidence that supports the involvement of AMPK in GDM by regulating skeletal muscle glucose metabolism and inflammation, which will be further discussed in the review.

\section{SIRT3}

Insulin resistance in skeletal muscle is associated with decreased mitochondrial metabolism and increased skeletal muscle oxidative stress in non-pregnant individuals (Koves et al. 2008, Anderson et al. 2009, Rains \& Jain 2011) and in pregnancies complicated by obesity and/or GDM (Boyle et al. 2013). In obese animal models, SIRT3 expression and activity are significantly reduced (Hirschey et al. 2011, Kendrick et al. 2011). Indeed, obese pregnant women have significantly increased levels of oxidative stress and reduced mitochondrial metabolic activity in skeletal muscle compared with non-obese pregnant women (Boyle et al. 2013). This increase in oxidative stress and altered mitochondrial activity corroborates with other studies in non-pregnant obese and insulin-resistant humans and animals (Koves et al. 2008, Anderson et al. 2009). GDM and obese pregnant women also have impaired antioxidant defence as determined by decreased MnSOD activity (Boyle et al. 2013). SIRT3 is the primary mitochondrial deacetylase in human skeletal muscle (Lombard et al. 2007) that is responsible for the activation of MnSOD enzymatic activity (Qiu et al. 2010, Tao et al. 2010, Finley et al. 2011). Acetylation is a reversible post-translational modification that is important for controlling enzyme activity involved in mitochondrial metabolism, including the citric acid cycle, fatty acid oxidation, electron transport system, antioxidant protection (Qiu et al. 2010, Tao et al. 2010, Finley et al. 2011). Although short-term high-fat diets increase SIRT3 gene expression, prolonged metabolic stress caused by chronic exposure to high-fat diets and the development of obesity are shown to downregulate SIRT3 (Hirschey et al. 2011). Notably, SIRT3-knockout mice share similar metabolic alternations that are common features of obesity, including signs of impaired skeletal muscle insulin signalling, increased oxidative stress/lipid peroxidation and reduced hepatic mitochondrial respiration (Ahn et al. 2008, Hirschey et al. 2011, Jing et al. 2011). Notably, obese normal glucose-tolerant women and obese GDM women had significantly reduced mitochondrial SIRT3 mRNA content and activity in their skeletal muscle compared to non-obese pregnant women (Boyle et al. 2013). In addition to adverse maternal health risks, GDM and obesity have long-term consequences for the offspring, such as increased risk of obesity and type 2 diabetes (Heerwagen et al. 2010, Strakovsky \& Pan 2012).

Recent studies also found reduced SIRT3 expression and activity in ECFCs and HUVECs from pregnancies complicated by GDM (Lappas 2012, Gui et al. 2016). This reduction of SIRTs may potentially the link the development of long-term cardiovascular complications in offspring of GDM pregnancies.

To date, there are limited studies on the role of SIRTs in regulating inflammation and insulin resistance associated with GDM. However, the studies discussed in this review have demonstrated SIRTs to exert protective effects against inflammation, endothelial cell dysfunction, oxidative stress and insulin resistance. Thus, SIRTs may be a potential therapeutic target in alleviating 
maternal and fetal complications that are commonly associated with GDM.

\section{$\mathrm{PI}$ KK/mTOR signalling}

The PI3K pathway is one of many mechanisms required for survival in environments with variable nutrient availability. Within the PI3K kinase family, there exists two protein complexes, namely mechanistic target of rapamycin complex (mTORC) 1 and mTORC2, each with distinct sensitivity to upstream and downstream regulation (Laplante \& Sabatini 2012). The mTOR pathway is a primary responder to environmental cues for energy availability, making it a crucial regulator of high energyconsuming processes, including cell proliferation and growth. A compromised mTOR signalling mechanism is thought to at least partially underlie various pathologies, including cancer and diabetes (Populo et al. 2012, Blagosklonny 2013).

Given these essential roles in cell metabolism, the mTOR pathway is a key regulator of maternal-fetal nutrient transport across the placenta (Wullschleger et al. 2006). The transfer of nutrients is key in dictating normal or abnormal growth of the fetus within the placenta and occurs across the microvillous and basal plasma membranes that form the syncytiotrophoblast through to the endothelium of fetal capillaries (Philipps et al. 1978). Amino acid transfer occurs from maternal blood to fetal blood through a process of active transport and key amino acid transporters. In cases of fetal macrosomia, it has been observed that the system A transporter for alanine, serine and glutamine has been upregulated in the microvillous membrane (Jansson et al. 2002). Similarly, increased activity within this membrane has also been observed in cases of diabetic pregnancies. Contrastingly, activity of this transporter is reduced in cases of intrauterine growth restriction (Jansson et al. 1998). Together, these data lead to the conclusion that the extent of growth within the fetus is largely dependent on the transport of nutrients across the placental barriers (Roos et al. 2009). It follows that pathways that underpin the transport of nutrients, such as the mTOR pathway, are essential in understanding how nutrient transfer affects fetal growth in both physiological and pathological conditions.

In an earlier study in cultured trophoblast cells, mTOR protein was found to regulate placental amino acid transfer in the placental epithelium, particularly through the L-amino acid transporter (Roos et al. 2007). Similarly, a study by Gaccioli et al. explored the role of the mTOR pathway in conjunction with the eukaryotic initiation factor (EIF)-2 in the regulation of protein synthesis (Gaccioli et al. 2013). Based on the notion that mTOR upregulates the uptake of nutrients in the placenta, researchers hypothesised that when the mother was overweight due to a high consumption of saturated fats, mTOR activity and subsequent nutrient transfer would be upregulated leading to overgrowth of the fetus. Moreover, high saturated fats in the diet leading to overweight would result in an inhibition of EIF-2 and inflammation of the placenta. These hypotheses were tested on a population of female pregnant rats fed a high-fat diet. The rats exhibited significantly higher triglyceride, insulin and leptin levels in both the mother and fetus, accompanied by increased weight. Interestingly, there was increased activation of mTORC1, despite no change in placental nutrient transporter activation and no evidence of increased placental inflammation. Thus, the predominant change was exerted through increased mTORC1 activity and additionally, decreased eIF2 alpha phosphorylation. Maternal hormones, including insulin, leptin and IGF-1 (Karl et al. 1992, Karl 1995, Jansson et al. 2003) are the mediators of placental nutrient transporters (Jones et al. 2007). Accordingly, obese NGT pregnancies are associated with elevated level of fasting insulin and leptin in late pregnancy (Ramsay et al. 2002) and second trimester insulin concentrations which are positively correlated with pre-pregnancy BMI (Clausen et al. 2005). Maternal hormones, including insulin, leptin and IGF-1 (Karl et al. 1992, Karl 1995, Jansson et al. 2003), have been described as regulators of placental nutrient transporters (Jones et al. 2007). Of interest, obese NGT pregnancies are associated with elevated level of fasting insulin and leptin in late pregnancy (Ramsay et al. 2002) and second trimester insulin concentrations which are positively correlated with pre-pregnancy BMI (Clausen et al. 2005). The increased circulation of hormones can mediate the upregulation of placental nutrient transport linking obese pregnancies and fetal overgrowth. Furthering this, Jansson et al.'s prospective study found that mTOR-dependent nutrient transport was implicated in fetal overgrowth by obese NGT mothers (Jansson et al. 2013). Of interest, high birth weight was positively correlated with the mTOR signalling pathway as well as the placental insulin and insulin-like growth factor pathways, while also being inversely correlated with AMPK phosphorylation. A positive correlation was also observed with the amino acid transporter system A within the microvillous plasma membrane. This led to the conclusion that fetal overgrowth with obese mothers may occur as a result of upregulated activity of amino acid transporters. 
Sati et al. recently compared the expression of mTOR pathway in placentas from normal term babies and GDM babies (Sati et al. 2016). In NGT term placentas, the syncytiotrophoblast and vascular walls of villi exhibited immunoreactive mTOR within the cytoplasm, as well as p-MTOR. However, there was increased expression of the ribosomal protein p-p70S6K in stromal cells of GDM placentas. As a downstream constituent of the mTOR signalling network, p-p70S6K overexpression indicates that mTOR plays a role in the observed pathology exhibited by the placenta of GDM births (Sati et al. 2016). Further functional analyses continue to be performed to further understand the distinct molecular pathways involved in these pathologies. However, the literature so far suggests placental GDM pathology, marked by overgrowth, is underpinned by an over activation of the mTOR pathway.

\section{Glycogen synthase kinase 3}

Glycogen synthase kinase 3 (GSK3) is a serine/threonine protein kinases that was originally found to play a role in the storage of glucose into glycogen (Woodgett 1990). In mammals, GSK3 exists as two isoforms: GSK3 $\alpha$ and GSK3 $\beta$ which although structurally similar are encoded by distinct genes and have different molecular weights of 51 and $47 \mathrm{kD}$, respectively (Woodgett 1990). GSK3 activity is regulated by the phosphorylation at one of its N-terminal serine (Ser) residues: ser21 in GSK3 $\alpha$ and ser9 in GSK3 $\beta$, causing its inactivation (Woodgett 1990). Although GSK3 $\alpha$ and GSK3 $\beta$ share many similar functions, they are not to be functionally redundant (Hoeflich et al. 2000). Subsequent studies revealed GSK3 $\beta$ is essential in a number of crucial cellular functions including cell cycle control, apoptosis, embryonic development, cell differentiation and adhesion (Frame \& Cohen 2001, Grimes \& Jope 2001, Doble \& Woodgett 2003, Jope \& Johnson 2004, Wang et al. 2011).

Overexpression of GSK3 in skeletal muscle of obese type 2 diabetic individuals and animal models of obesity is associated with insulin resistance. For example, in type 2 diabetes, the early development of insulin resistance as indicated by impaired glycogen synthesis is associated with increased GSK3 activity in vivo (Eldar-Finkelman et al. 1999). Furthermore, using type 2 diabetes animal models, GSK3 $\beta$ inhibitor CHIR99021 improves insulin sensitivity and glucose metabolism (Cline et al. 2002, Ring et al. 2003). Interestingly, suppression of GSK3 $\alpha / \beta$ is also associated with decreased inflammation in response to pro-inflammatory stimuli including TNF- $\alpha$, IL- $1 \beta$ and LPS (Martin et al. 2005). More recently, increased GSK3 activity has been linked to a number of inflammatory diseases, including diabetes (Jope et al. 2007, Rayasam et al. 2009). GSK3 activity is significantly increased in nonpregnant obese and diabetic adipose tissue and skeletal muscle (Eldar-Finkelman et al. 1999, Nikoulina et al. 2000). Likewise, women with GDM have significantly reduced GSK3 $\beta$ serine phosphorylation in their skeletal muscle and omental adipose tissue (Lappas 2014c). Given this increase in GSK3 $\beta$ activity with GDM, the role of GSK3 in regulating GDM associated inflammation has been explored. The GSK3 inhibitor CHIR99021 significantly reduced the gene expression and secretion of pro-inflammatory mediators (TNF- $\alpha$, IL- $1 \beta$, IL-6, IL- 8 and MCP-1) in adipose tissue and skeletal muscle stimulated with LPS or IL-1 $\beta$ (Lappas 2014c). Furthermore, GSK3 inhibition significantly decreased LPS or IL-1 $\beta$ induced expression and secretion of the cell adhesion molecules VCAM-1 and ICAM-1 (Lappas 2014c).

The precise mechanism that GSK3 regulates inflammation in pregnant adipose tissue and skeletal muscle is not known. However, GSK3 is necessary for the full transcriptional activity of NF-kB (Hoeflich et al. 2000, Martin et al. 2005). The gene transcription co-activator $\beta$-catenin plays an important role in GSK-mediated regulation of NF- $\mathrm{BB}$ gene transcription. GSK3 inactivation leads to the translocation of $\beta$-catenin from the cytoplasm to the nucleus, which in turn blocks NF- $\mathrm{kB}$ activity (Kim et al. 2014). Whether GSK3 regulates NF-кB activity in pregnant adipose tissue and skeletal muscle is not known.

\section{Adenosine monophosphate (AMP)-activated protein kinase (AMPK)}

Adenosine monophosphate (AMP)-activated protein kinase (AMPK) is a serine/threonine protein kinase that is formed from three heterogenic subunits, a catalytic $(\alpha)$ subunit and two regulatory subunits ( $\beta$ and $\gamma$ ). There is considerable evidence that AMPK regulates skeletal muscle glucose metabolism and inflammation (Hayashi et al. 1998, Lihn et al. 2008). Of note, in non-pregnant obese and diabetic individuals, AMPK activity in skeletal muscle and adipose tissue is diminished or impaired compared to normal healthy individuals (Sriwijitkamol et al. 2007, $\mathrm{Xu}$ et al. 2012). Recent data have also revealed that AMPK activity is significantly reduced in skeletal muscle and adipose tissue of women with GDM (Boyle et al. 2014, Liong \& Lappas 2015a).

AMPK activators diminish inflammation in response to LPS and IL-1 $\beta$ stimuli (Giri et al. 2004, Dasu et al. 2008). Studies in skeletal muscle and adipose tissue from 
pregnant women have shown AMPK activators AICAR and phenformin to significantly reduce LPS or IL-1 $\beta$-stimulated production of pro-inflammatory cytokines IL-6, IL-8 and MCP-1 (Liong \& Lappas 2015a). The precise mechanism(s) by which AMPK regulates inflammation and insulin sensitivity in skeletal muscle remains known. In skeletal muscle myoblasts, AMPK activates the histone/protein deacetylase and anti-inflammatory molecule sirtuin 1 (SIRT1) (Lappas et al. 2011b). It has been proposed that AMPK activators can upregulate SIRT1 activity resulting in the decreased production of bacterially induced proinflammatory mediators in human gestational tissues (Lappas et al. 2011b). Studies have also described AMPK to suppress the activity of the pro-inflammatory transcription NF- $\kappa$ B. For example, AICAR and phenformin block NF-кB signalling stimulated by LPS (Katerelos et al. 2010). It is thought that AMPK suppresses NF- $\kappa B$ signalling indirectly via its downstream inhibitory mediators such as SIRT1, Forkhead box O (FoxO) family, and peroxisome proliferator-activated receptor $\gamma$ co-activator $1 \alpha$ (PGC- $1 \alpha$ ) (Salminen et al. 2011).

\section{Inflammasome}

The inflammasome is a large multi-subunit protein complex that processes IL-1 $\beta$ from its precursor form to its secreted active form. In pregnant adipose tissue, TLRs and pro-inflammatory cytokine signalling pathways play a crucial role in IL-1 $\beta$ secretion via the inflammasome (Lappas 2014a). Of note, activation of the inflammasome significantly augments IL-1 $\beta$ production while simultaneously decreasing AMPK activity in pregnant skeletal muscle and adipose tissue (Liong \& Lappas 2015a). As a result, insulin-mediated glucose uptake and activation of the insulin signalling pathway (i.e. IRS-1, IR- $\beta$ and GLUT- 4 ) were significantly impaired compared to basal conditions (Lappas 2014a, Liong \& Lappas 2015a). Therefore, the finding that women with GDM exhibit increased inflammasome activation in their adipose tissue is of great concern (Lappas 2014a).

Interestingly, AMPK activation by the AICAR activator rescued insulin resistance induced by IL-1 $\beta$ (Liong \& Lappas 2015a). Other in vivo studies have found AMPK activation resulted in improved insulin resistance, glucose metabolism and fetal outcomes in GDM mice (Yao et al. 2015). In the liver, AMPK regulates glucose production, by inhibiting histone acetyltransferase (HDACs) enzymes, resulting in the downregulation of glucose 6-phosphatase (G6Pase) expression and activity (Mihaylova et al. 2011). Given that AMPK has been shown to be an important regulator of inflammation and glucose metabolism, further studies are warranted to assess its role as a therapeutic target for GDM.

\section{ER stress}

ER stress is characterised by the accumulation of misfolded proteins in the ER lumen (Zhang et al. 2009, Hotamisligil 2010, McGuckin et al. 2010, Garg et al. 2012, Verfaillie et al. 2013) and is associated with a number of metabolic disease, including obesity and diabetes (Ozcan et al. 2004, 2006). It is thought that various endogenous and exogenous cellular insults, including environmental toxins, inflammation and viral infection, disturb the protein folding environment, thus activating the unfolded protein response (UPR). The UPR is mediated by three distinct arms, each activated by either the inositolrequiring enzyme 1 (IRE1), activating transcription factor 6 (ATF6) or pancreatic endoplasmic reticulum kinase (PERK). Through these signalling proteins, the UPR alleviates ER stress by inhibiting protein translation, removing misfolded proteins and increasing the ER protein folding capacity. However, if the UPR fails to alleviate ER stress, the cells will subsequently undergo caspase-mediated apoptosis (Nakagawa et al. 2000).

Recent evidence has implicated the IRE1 pathway of the UPR to regulate inflammation. Activation of the IRE1 pathway induces the production of proinflammatory cytokines such IL-8, IL-6, and TNF- $\alpha$ (Gargalovic et al. 2006, Martinon et al. 2010), and NF-кB activation via IкB degradation (Kaneko et al. 2003, Hu et al. 2006). Moreover, NF-кB-mediated production of pro-inflammatory cytokines activate ER stress and thus augment the inflammatory state (Zhang et al. 2006b). More recently, studies have identified the IRE1 pathway to activate the inflammasome complex and secretion of IL-1 $\beta$ (Kim et al. 2013a).

There is mounting evidence to show ER stress plays a central role in peripheral insulin resistance, obesity and type 2 diabetes (Ozcan et al. 2004, 2006). Studies in obese and diabetic mice have demonstrated a significant reduction in weight gain and improved insulin sensitivity in the liver, adipose tissue and muscle when administered with ER stress inhibitor 4-phenylbutyric acid (4-PBA) (Ozcan et al. 2006, Basseri et al. 2009). In pregnant women, ER stress is significantly increased in adipose tissue and skeletal muscle of women with GDM and with maternal obesity (Liong \& Lappas 2015b, 2016). Recent studies have described the IRE1 arm of the ER stress signalling pathway in propagating inflammation associated with GDM pregnancies. 
Table 1 Summary of changes in the expression or activity of pathways in adipose tissue, placenta and skeletal muscle of GDM pregnancies compared to normal pregnancies.

\begin{tabular}{|c|c|c|c|}
\hline \multirow[b]{2}{*}{ Pathways } & \multicolumn{3}{|c|}{$\begin{array}{l}\text { Expression/activity in GDM compared to } \\
\text { NGT pregnancies }\end{array}$} \\
\hline & Adipose tissue & Placenta & Skeletal muscle \\
\hline NF-кB & - & $\uparrow$ & - \\
\hline TLRs & - & $\uparrow$ TLR4 & - \\
\hline NODs & $\uparrow \mathrm{NOD} 1$ & - & - \\
\hline PPARs & $\downarrow$ PPAR $\gamma$ & $\downarrow$ PPAR $\alpha$, PPAR $\gamma$ & - \\
\hline SIRTS & - & $\downarrow$ SIRT1, SIRT3 & $\downarrow$ SIRT3 \\
\hline PI3K & $\uparrow$ & $\downarrow$ & $\downarrow$ \\
\hline mTOR & - & $\uparrow$ & - \\
\hline GSK3 & $\uparrow$ & - & $\uparrow$ \\
\hline AMPK & $\downarrow$ & $\downarrow$ & $\downarrow$ \\
\hline Inflammasome & $\uparrow$ & - & - \\
\hline ER stress & $\uparrow$ & $\uparrow$ & $\uparrow$ \\
\hline
\end{tabular}

$\uparrow$, increased in expression/activity; $\downarrow$, decreased in expression/activity; -, no findings reported.

For example, either the ER stress inhibitor TUDCA or siRNAinduced gene silencing of ER stress markers GRP78, ATF6 or IRE1 $\alpha$ significantly abolishes inflammation induced by toll-like receptors (TLR3, TLR4) or cytokines (IL-1 $\beta$ ) in pregnant skeletal muscle (Liong \& Lappas 2016). Further, mRNA expression of IRE1 $\alpha$, GRP78, XBP-1 and ATF6 was significantly increased in skeletal muscle stimulated with
IL-1 $\beta$, LPS (TLR3 ligand) and poly(I:C) (TLR4 ligand) and was subsequently suppressed following TUDCA treatment. Studies in adipose tissue of pregnant women also found ER stress to be a key activator of the inflammasome complex and that the secretion of IL- $1 \beta$ is regulated by ER stress (Liong \& Lappas 2015b). In vivo studies have also shown ER stress inhibitors attenuate inflammasome activation in diabetic mice (Fang et al. 2013). Inhibition of ER stress by GRP78, ATF6 or IRE1 $\alpha$ siRNA gene silencing or with TUDCA treatment also restored the insulin signalling pathway and insulin-mediated glucose uptake in skeletal muscle impaired by LPS, poly(I:C) and TNF- $\alpha$ to basal levels (Liong \& Lappas 2016).

In summary, ER stress may contribute to inflammation and insulin resistance that is characteristic of GDM and obese pregnancies. Of promise is the safe use of TUDCA in humans, which is currently used as a treatment for cholestatic liver diseases (Beuers 2006), and thus could have therapeutic applications in suppressing inflammation and improving peripheral insulin resistance associated with GDM.

\section{Concluding remarks}

The lifelong and severe health complications directly resulting for GDM for both mother and child cannot be

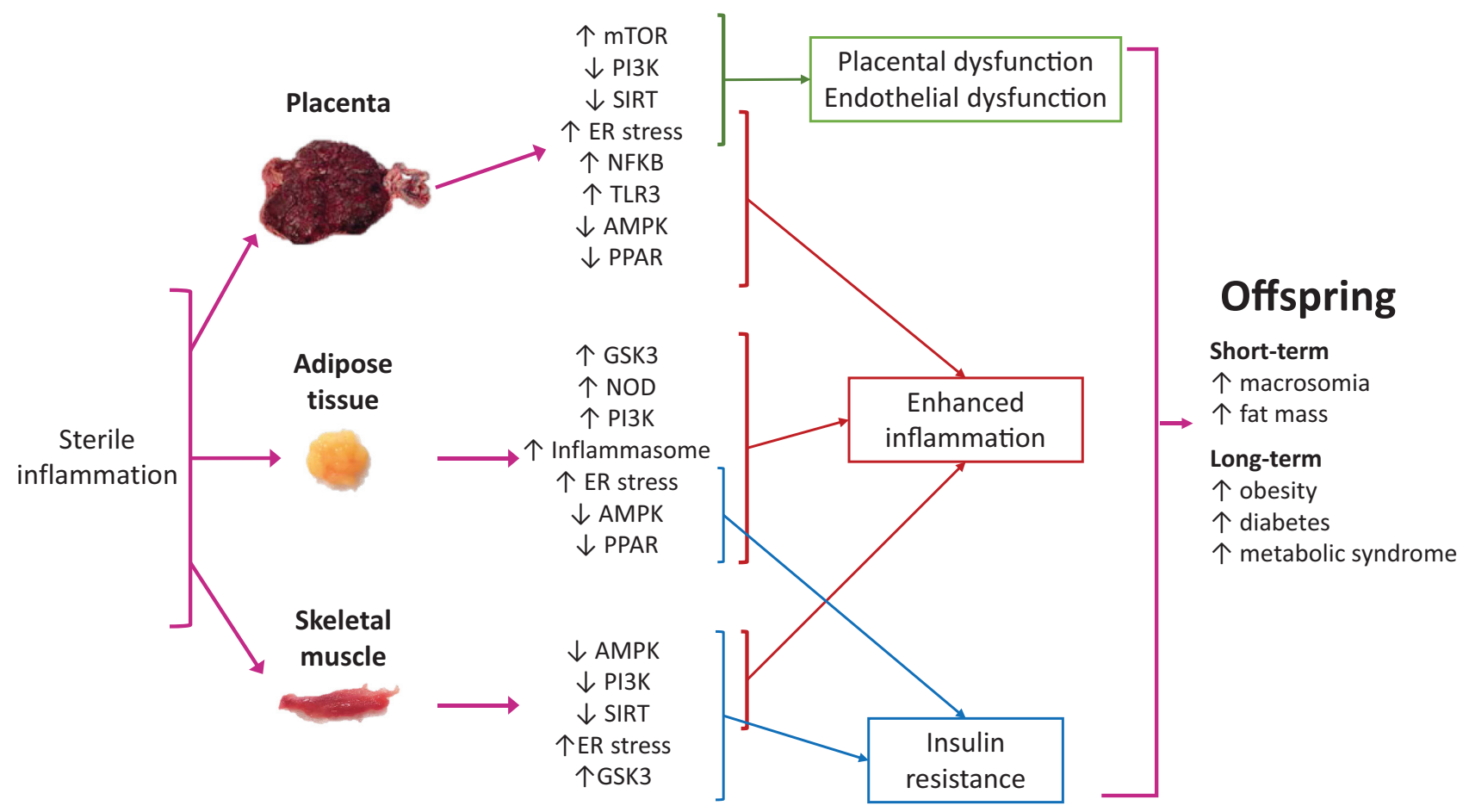

Figure 1

Model of GDM. Sterile inflammatory insults dysregulate the expression and/or activity of various signalling pathways in placenta, adipose tissue and skeletal muscle leading to altered function in these tissues which can contribute to adverse offspring outcomes associated with GDM. 
ignored. GDM not only contributes heavily to obstetric and perinatal morbidity, but leaves a legacy of future longterm health risks that places an extraordinary economic burden on our healthcare system. A better understanding of the regulatory pathways involved in GDM may lead to the identification of molecular targets for therapy. It is important that any potential pharmaceutical use during pregnancy also needs to consider the impact on the developing fetus. Such therapies would significantly reduce public health costs and improve the lives of women and babies for generations to come.

As described earlier, a number of signalling pathways may play a role in the pathophysiology of GDM; see Table 1 for a summary of the data. Though this review discusses the key pathways of GDM development in a non-hierarchical manner, we are able to glean from T2DM studies that these key pathways often interact with and alongside each other. Unfortunately, there is no evidence in GDM to indicate that these pathways act in a hierarchical manner to contribute to GDM development. We postulate that sterile inflammatory insults dysregulate the expression and or activity of various signalling pathways in placenta, adipose tissue and skeletal muscle leading to altered function in these tissues which can contribute to adverse offspring outcomes associated with GDM (Fig. 1). These signalling pathways represent potential targets for improving both short- and long-term health outcomes of offspring complicated by GDM pregnancies.

\section{Declaration of interest}

The authors declare that there is no conflict of interest that could be perceived as prejudicing the impartiality of this review.

\section{Funding}

Associate Professor Martha Lappas is supported by a Research Fellowship from the Department of Obstetrics and Gynaecology (University of Melbourne) and a Faculty Fellowship from the University of Melbourne. Caitlyn Nguyen-Ngo is supported by an Australian Government Research Training Program (RTP) Scholarship. Nanthini Jayabalan is supported by Scholarship of Public Service Department of Malaysia (JPA). The work from M Lappas's laboratory was funded by project grants from NHMRC (grant no. 454310), Norman Beischer Medical Research Foundation, Diabetes Australia, Melbourne Research Grant Scheme (MRGS), ANZ Charitable Trust (Medical Research and Technology Grant), and Mercy Research Foundation. Dr Carlos Salomon is supported by Lions Medical Research Foundation, National Health and Medical Research Council (NHMRC; 1114013), Diabetes Australia, and Fondo Nacional de Desarrollo Científico y Tecnológico (FONDECYT 1170809).

\section{References}

Abell SK, de Courten B, Boyle JA \& Teede HJ 2015 Inflammatory and other biomarkers: role in pathophysiology and prediction of gestational diabetes mellitus. International Journal of Molecular Sciences 16 13442-13473. (https://doi.org/10.3390/ijms160613442)

Aguirre V, Werner ED, Giraud J, Lee YH, Shoelson SE \& White MF 2002 Phosphorylation of Ser307 in insulin receptor substrate-1 blocks interactions with the insulin receptor and inhibits insulin action. Journal of Biological Chemistry 277 1531-1537. (https://doi. org/10.1074/jbc.M101521200)

Ahn BH, Kim HS, Song S, Lee IH, Liu J, Vassilopoulos A, Deng CX \& Finkel T 2008 A role for the mitochondrial deacetylase Sirt3 in regulating energy homeostasis. PNAS 105 14447-14452. (https://doi. org/10.1073/pnas.0803790105)

Anderson EJ, Lustig ME, Boyle KE, Woodlief TL, Kane DA, Lin CT, Price 3rd JW, Kang L, Rabinovitch PS, Szeto HH, et al. 2009 Mitochondrial $\mathrm{H} 2 \mathrm{O} 2$ emission and cellular redox state link excess fat intake to insulin resistance in both rodents and humans. Journal of Clinical Investigation 119 573-581. (https://doi.org/10.1172/JCI37048)

Anna Turek I, Wozniak L, Cypryk K, Nadel I \& Wojcik M 2014 Evaluation of leukocyte SIRT1 expression in women with gestational diabetes mellitus (GDM) in the third trimester of pregnancy. Diabetologia Kliniczna 3 3-11.

Arck P, Toth B, Pestka A \& Jeschke U 2010 Nuclear receptors of the peroxisome proliferator-activated receptor (PPAR) family in gestational diabetes: from animal models to clinical trials. Biology of Reproduction 83 168-176. (https://doi.org/10.1095/ biolreprod.110.083550)

Assche FA, Aerts L \& Prins FD 1978 A morphological study of the endocrine pancreas in human pregnancy. British Journal of Obstetrics and Gynaecology 85 818-820. (https://doi.org/10.1111/ j.1471-0528.1978.tb15835.x)

Ategbo JM, Grissa O, Yessoufou A, Hichami A, Dramane KL, Moutairou K, Miled A, Grissa A, Jerbi M, Tabka Z, et al. 2006 Modulation of adipokines and cytokines in gestational diabetes and macrosomia. Journal of Clinical Endocrinology and Metabolism 91 4137-4143. (https://doi.org/10.1210/jc.2006-0980)

Aye ILMH, Waddell BJ, Mark PJ \& Keelan JA 2012 Oxysterols exert proinflammatory effects in placental trophoblasts via TLR4dependent, cholesterol-sensitive activation of NF-kappa B. Molecular Human Reproduction 18 341-353. (https://doi.org/10.1093/molehr/ gas001)

Baeyens L, Hindi S, Sorenson RL \& German MS 2016 Beta-cell adaptation in pregnancy. Diabetes, Obesity and Metabolism 18 (Supplement 1) 63-70. (https://doi.org/10.1111/dom.12716)

Baldwin AS 1996 The NF-kappa B and I kappa B proteins: new discoveries and insights. Annual Review of Immunology 14 649-683. (https://doi.org/10.1146/annurev.immunol.14.1.649)

Barbour LA 2003 New concepts in insulin resistance of pregnancy and gestational diabetes: long-term implications for mother and offspring. Journal of Obstetrics and Gynaecology 23 545-549. (https:// doi.org/10.1080/0144361031000156500)

Barbour LA, Shao J, Qiao L, Leitner W, Anderson M, Friedman JE \& Draznin B 2004 Human placental growth hormone increases expression of the p 85 regulatory unit of phosphatidylinositol 3-kinase and triggers severe insulin resistance in skeletal muscle. Endocrinology 145 1144-1150. (https://doi.org/10.1210/en.20031297)

Barbour LA, Mccurdy CE, Hernandez TL, de la Houssaye BE, Draznin B \& Friedman JE 2006 Reduced IRS-1 and increased serine IRS-1 phosphorylation skeletal muscle from women with GDM. Diabetes 55 A39-A40.

Bari MF, Weickert MO, Sivakumar K, James SG, Snead DR, Tan BK, Randeva HS, Bastie CC \& Vatish M 2014 Elevated soluble CD163 in gestational diabetes mellitus: secretion from human placenta and adipose tissue. PLoS ONE 9 e101327. (https://doi.org/10.1371/ journal.pone.0101327)

Barton GM \& Medzhitov R 2003 Toll-like receptor signaling pathways. Science 300 1524-1525. (https://doi.org/10.1126/science.1085536) 
Basseri S, Lhotak S, Sharma AM \& Austin RC 2009 The chemical chaperone 4-phenylbutyrate inhibits adipogenesis by modulating the unfolded protein response. Journal of Lipid Research 50 2486-2501. (https://doi.org/10.1194/jlr.M900216-JLR200)

Baumann MU, Schneider H, Malek A, Palta V, Surbek DV, Sager R, Zamudio S \& Illsley NP 2014 Regulation of human trophoblast GLUT1 glucose transporter by insulin-like growth factor I (IGF-I). PLOS ONE 9 e106037. (https://doi.org/10.1371/journal.pone.0106037)

Beck P, Parker ML \& Daughaday WH 1965 Radioimmunologic measurement of human placental lactogen in plasma by a double antibody method during normal and diabetic pregnancies. Journal of Clinical Endocrinology and Metabolism 25 1457-1462. (https://doi. org/10.1210/jcem-25-11-1457)

Beischer NA, Oats JN, Henry OA, Sheedy MT \& Walstab JE 1991 Incidence and severity of gestational diabetes mellitus according to country of birth in women living in Australia. Diabetes $\mathbf{4 0}$ (Supplement 2) 35-38. (https://doi.org/10.2337/diab.40.2.s35)

Bellamy L, Casas JP, Hingorani AD \& Williams D 2009 Type 2 diabetes mellitus after gestational diabetes: a systematic review and metaanalysis. Lancet 373 1773-1779. (https://doi.org/10.1016/S01406736(09)60731-5)

Beuers U 2006 Drug insight: mechanisms and sites of action of ursodeoxycholic acid in cholestasis. Nature Clinical Practice: Gastroenterology and Hepatology 3 318-328. (https://doi.org/10.1038/ ncpgasthep0521)

Binder AM, Larocca J, Lesseur C, Marsit CJ \& Michels KB 2015 Epigenome-wide and transcriptome-wide analyses reveal gestational diabetes is associated with alterations in the human leukocyte antigen complex. Clinical Epigenetics 7 79. (https://doi.org/10.1186/ s13148-015-0116-y)

Blagosklonny MV 2013 TOR-centric view on insulin resistance and diabetic complications: perspective for endocrinologists and gerontologists. Cell Death and Disease 4 e964. (https://doi. org/10.1038/cddis.2013.506)

Bottalico JN 2007 Recurrent gestational diabetes: risk factors, diagnosis, management, and implications. Seminars in Perinatology 31 176-184. (https://doi.org/10.1053/j.semperi.2007.03.006)

Boyle KE, Newsom SA, Janssen RC, Lappas M \& Friedman JE 2013 Skeletal muscle MnSOD, mitochondrial complex II, and SIRT3 enzyme activities are decreased in maternal obesity during human pregnancy and gestational diabetes mellitus. Journal of Clinical Endocrinology and Metabolism 98 E1601-E1609. (https://doi. org/10.1210/jc.2013-1943)

Boyle KE, Hwang H, Janssen RC, Devente JM, Barbour LA, Hernandez TL, Mandarino LJ, Lappas M \& Friedman JE 2014 Gestational diabetes is characterized by reduced mitochondrial protein expression and altered calcium signaling proteins in skeletal muscle. PLOS ONE 9 e106872. (https://doi.org/10.1371/journal. pone.0106872)

Branisteanu DD \& Mathieu C 2003 Progesterone in gestational diabetes mellitus: guilty or not guilty? Trends in Endocrinology and Metabolism 14 54-56. (https://doi.org/10.1016/S1043-2760(03)00003-1)

Brizzi P, Tonolo G, Esposito F, Puddu L, Dessole S, Maioli M \& Milia S 1999 Lipoprotein metabolism during normal pregnancy. American Journal of Obstetrics and Gynecology 181 430-434. (https://doi. org/10.1016/s0002-9378(99)70574-0)

Burns J, Yokota T, Ashihara H, Lean ME \& Crozier A 2002 Plant foods and herbal sources of resveratrol. Journal of Agricultural and Food Chemistry 50 3337-3340. (https://doi.org/10.1021/jf0112973)

Catalano PM, Tyzbir ED, Roman NM, Amini SB \& Sims EA 1991 Longitudinal changes in insulin release and insulin resistance in nonobese pregnant women. American Journal of Obstetrics and Gynecology 165 1667-1672. (https://doi.org/10.1016/00029378(91)90012-g)

Catalano PM, Nizielski SE, Shao J, Preston L, Qiao L \& Friedman JE 2002 Downregulated IRS-1 and PPARgamma in obese women with gestational diabetes: relationship to FFA during pregnancy. American Journal of Physiology: Endocrinology and Metabolism 282 E522-E533. (https://doi.org/10.1152/ajpendo.00124.2001)

Catalano PM, Kirwan JP, Haugel-de Mouzon S \& King J 2003a Gestational diabetes and insulin resistance: role in short- and longterm implications for mother and fetus. Journal of Nutrition 133 1674S-1683S. (https://doi.org/10.1093/jn/133.5.1674S)

Catalano PM, Thomas A, Huston-Presley L \& Amini SB $2003 b$ Increased fetal adiposity: a very sensitive marker of abnormal in utero development. American Journal of Obstetrics and Gynecology 189 1698-1704. (https://doi.org/10.1016/s0002-9378(03)00828-7)

Casanello P, Escudero C \& Sobrevia L 2007 Equilibrative nucleoside (ENTs) and cationic amino acid (CATs) transporters: implications in foetal endothelial dysfunction in human pregnancy diseases. Current Vascular Pharmacology 5 69-84. (https://doi. org/10.2174/157016107779317198)

Cedergren MI 2004 Maternal morbid obesity and the risk of adverse pregnancy outcome. Obstetrics and Gynecology 103 219-224. (https:// doi.org/10.1097/01.AOG.0000107291.46159.00)

Cheatham B, Vlahos CJ, Cheatham L, Wang L, Blenis J \& Kahn CR 1994 Phosphatidylinositol 3-kinase activation is required for insulin stimulation of pp70 S6 kinase, DNA synthesis, and glucose transporter translocation. Molecular and Cellular Biology $144902-$ 4911. (https://doi.org/10.1128/mcb.14.7.4902)

Chen J, Zhou Y, Mueller-Steiner S, Chen LF, Kwon H, Yi S, Mucke L \& Gan L 2005 SIRT1 protects against microglia-dependent amyloidbeta toxicity through inhibiting NF-kappaB signaling. Journal of Biological Chemistry 280 40364-40374. (https://doi.org/10.1074/jbc. M509329200)

Chirayath HH, Wareing M, Taggart MJ \& Baker PN 2010 Endothelial dysfunction in myometrial arteries of women with gestational diabetes. Diabetes Research and Clinical Practice 89 134-140. (https:// doi.org/10.1016/j.diabres.2010.03.022)

Chu SY, Callaghan WM, Kim SY, Schmid CH, Lau J, England LJ \& Dietz PM 2007 Maternal obesity and risk of gestational diabetes mellitus. Diabetes Care 30 2070-2076. (https://doi.org/10.2337/dc06-2559a)

Clausen T, Burski TK, Oyen N, Godang K, Bollerslev J \& Henriksen T 2005 Maternal anthropometric and metabolic factors in the first half of pregnancy and risk of neonatal macrosomia in term pregnancies. A prospective study. European Journal of Endocrinology 153 887-894. (https://doi.org/10.1530/eje.1.02034)

Cline GW, Johnson K, Regittnig W, Perret P, Tozzo E, Xiao L, Damico C \& Shulman GI 2002 Effects of a novel glycogen synthase kinase-3 inhibitor on insulin-stimulated glucose metabolism in Zucker diabetic fatty (fa/fa) rats. Diabetes 51 2903-2910. (https://doi. org/10.2337/diabetes.51.10.2903)

Colomiere M, Permezel M, Riley C, Desoye G \& Lappas M 2009 Defective insulin signaling in placenta from pregnancies complicated by gestational diabetes mellitus. European Journal of Endocrinology 160 567-578. (https://doi.org/10.1530/EJE-09-0031)

Dabelea D, Hanson RL, Lindsay RS, Pettitt DJ, Imperatore G, Gabir MM, Roumain J, Bennett PH \& Knowler WC 2000 Intrauterine exposure to diabetes conveys risks for type 2 diabetes and obesity: a study of discordant sibships. Diabetes 49 2208-2211. (https://doi.org/10.2337/ diabetes.49.12.2208)

Dasu MR, Devaraj S, Zhao L, Hwang DH \& Jialal I 2008 High glucose induces toll-like receptor expression in human monocytes: mechanism of activation. Diabetes 57 3090-3098. (https://doi. org/10.2337/db08-0564)

De Souza LR, Berger H, Retnakaran R, Maguire JL, Nathens AB, Connelly PW \& Ray JG 2016 First-trimester maternal abdominal adiposity predicts dysglycemia and gestational diabetes mellitus in midpregnancy. Diabetes Care 39 61-64. (https://doi.org/10.2337/ dc15-2027)

Dekker Nitert M, Barrett HL, Kubala MH, Scholz Romero K, Denny KJ, Woodruff TM, Mcintyre HD \& Callaway LK 2014 Increased placental 
expression of fibroblast growth factor 21 in gestational diabetes mellitus. Journal of Clinical Endocrinology and Metabolism 99 E591E598. (https://doi.org/10.1210/jc.2013-2581)

Del Aguila LF, Claffey KP \& Kirwan JP 1999 TNF-alpha impairs insulin signaling and insulin stimulation of glucose uptake in C2C12 muscle cells. American Journal of Physiology 276 E849-E855. (https://doi. org/10.1152/ajpendo.1999.276.5.E849)

Deopurkar R, Ghanim H, Friedman J, Abuaysheh S, Sia CL, Mohanty P, Viswanathan P, Chaudhuri A \& Dandona P 2010 Differential effects of cream, glucose, and orange juice on inflammation, endotoxin, and the expression of Toll-like receptor-4 and suppressor of cytokine signaling-3. Diabetes Care 33 991-997. (https://doi.org/10.2337/dc091630)

Desoye G, Hartmann M, Blaschitz A, Dohr G, Hahn T, Kohnen G \& Kaufmann P 1994 Insulin receptors in syncytiotrophoblast and fetal endothelium of human placenta. Immunohistochemical evidence for developmental changes in distribution pattern. Histochemistry 101 277-285. (https://doi.org/10.1007/BF00315915)

Desoye G, Hartmann M, Jones CJ, Wolf HJ, Kohnen G, Kosanke G \& Kaufmann P 1997 Location of insulin receptors in the placenta and its progenitor tissues. Microscopy Research and Technique 38 63-75. (https://doi.org/10.1002/(SICI)10970029(19970701/15)38:1/2<63::AID-JEMT8>3.0.CO;2-V)

Di Fulvio P, Pandolfi A, Formoso G, Di Silvestre S, Di Tomo P, Giardinelli A, De Marco A, Di Pietro N, Taraborrelli M, Sancilio S, et al. 2014 Features of endothelial dysfunction in umbilical cord vessels of women with gestational diabetes. Nutrition, Metabolism, and Cardiovascular Diseases 24 1337-1345. (https://doi.org/10.1016/j. numecd.2014.06.005)

Díaz P, Dimasuay KG, Koele-Schmidt L, Jang B, Barbour LA, Jansson T \& Powell TL 2017 Glyburide treatment in gestational diabetes is associated with increased placental glucose transporter 1 expression and higher birth weight. Placenta 57 52-59. (https://doi. org/10.1016/j.placenta.2017.05.016)

Doble BW \& Woodgett JR 2003 GSK-3: tricks of the trade for a multitasking kinase. Journal of Cell Science 116 1175-1186. (https://doi. org/10.1242/jcs.00384)

Eldar-Finkelman H, Schreyer SA, Shinohara MM, Leboeuf RC \& Krebs EG 1999 Increased glycogen synthase kinase-3 activity in diabetes- and obesity-prone C57BL/6J mice. Diabetes 48 1662-1666. (https://doi. org/10.2337/diabetes.48.8.1662)

Endo S, Maeda K, Suto M, Kaji T, Morine M, Kinoshita T, Yasui T \& Irahara M 2006 Differences in insulin sensitivity in pregnant women with overweight and gestational diabetes mellitus. Gynecological Endocrinology 22 343-349. (https://doi. org/10.1080/09513590600724836)

Enquobahrie DA, Williams MA, Qiu C, Meller M \& Sorensen TK 2009 Global placental gene expression in gestational diabetes mellitus. American Journal of Obstetrics and Gynecology 200 206.e1-206.13. (https://doi.org/10.1016/j.ajog.2008.08.022)

Fang L, Xie D, Wu X, Cao H, Su W \& Yang J 2013 Involvement of endoplasmic reticulum stress in albuminuria induced inflammasome activation in renal proximal tubular cells. PLOS ONE 8 e72344. (https://doi.org/10.1371/journal.pone.0072344)

Feng H, Su R, Song Y, Wang C, Lin LJ \& Yang H 2016 Positive correlation between enhanced expression of TLR4/MyD88/ NF-kappaB with insulin resistance in placentae of gestational diabetes mellitus. PLoS ONE 11 e0157185. (https://doi.org/10.1371/ journal.pone.0157185)

Ferrara A 2007 Increasing prevalence of gestational diabetes mellitus: a public health perspective. Diabetes Care 30 (Supplement 2) S141-S146. (https://doi.org/10.2337/dc07-s206)

Finley LW, Haas W, Desquiret-Dumas V, Wallace DC, Procaccio V, Gygi SP \& Haigis MC 2011 Succinate dehydrogenase is a direct target of sirtuin 3 deacetylase activity. PLOS ONE 6 e23295. (https://doi. org/10.1371/journal.pone.0023295)
Frame S \& Cohen P 2001 GSK3 takes centre stage more than 20 years after its discovery. Biochemical Journal 359 1-16. (https://doi. org/10.1042/0264-6021:3590001)

Franchi L, Warner N, Viani K \& Nunez G 2009 Function of Nod-like receptors in microbial recognition and host defense. Immunological Reviews 227 106-128. (https://doi. org/10.1111/j.1600-065X.2008.00734.X)

Fritz JH, Ferrero RL, Philpott DJ \& Girardin SE 2006 Nod-like proteins in immunity, inflammation and disease. Nature Immunology 7 12501257. (https://doi.org/10.1038/ni1412)

Gaccioli F, White V, Capobianco E, Powell TL, Jawerbaum A \& Jansson T 2013 Maternal overweight induced by a diet with high content of saturated fat activates placental mTOR and eIF2alpha signaling and increases fetal growth in rats. Biology of Reproduction 89 96. (https:// doi.org/10.1095/biolreprod.113.109702)

Gaither K, Quraishi AN \& Illsley NP 1999 Diabetes alters the expression and activity of the human placental GLUT1 glucose transporter. Journal of Clinical Endocrinology and Metabolism 84 695-701. (https:// doi.org/10.1210/jcem.84.2.5438)

Ganss R 2017 Maternal metabolism and vascular adaptation in pregnancy: the PPAR link. Trends in Endocrinology and Metabolism 28 73-84. (https://doi.org/10.1016/j.tem.2016.09.004)

Garg AD, Kaczmarek A, Krysko O, Vandenabeele P, Krysko DV \& Agostinis P 2012 ER stress-induced inflammation: does it aid or impede disease progression? Trends in Molecular Medicine 18 589-598. (https://doi.org/10.1016/j.molmed.2012.06.010)

Gargalovic PS, Gharavi NM, Clark MJ, Pagnon J, Yang WP, He A, Truong A, Baruch-Oren T, Berliner JA, Kirchgessner TG, et al. 2006 The unfolded protein response is an important regulator of inflammatory genes in endothelial cells. Arteriosclerosis, Thrombosis, and Vascular Biology 26 2490-2496. (https://doi.org/10.1161/01. ATV.0000242903.41158.a1)

Ghanim H, Abuaysheh S, Sia CL, Korzeniewski K, Chaudhuri A, Fernandez-Real JM \& Dandona P 2009 Increase in plasma endotoxin concentrations and the expression of toll-like receptors and suppressor of cytokine signaling- 3 in mononuclear cells after a high-fat, high-carbohydrate meal implications for insulin resistance. Diabetes Care 32 2281-2287. (https://doi.org/10.2337/ dc09-0979)

Gibson KS, Waters TP \& Catalano PM 2012 Maternal weight gain in women who develop gestational diabetes mellitus. Obstetrics and Gynecology 119 560-565. (https://doi.org/10.1097/ AOG.0b013e31824758e0)

Gillespie P, Cullinan J, O’Neill C, Dunne F \& ATLANTIC DIP Collaborators 2013 Modeling the independent effects of gestational diabetes mellitus on maternity care and costs. Diabetes Care $\mathbf{3 6}$ 1111-1116. (https://doi.org/10.2337/dc12-0461)

Giri S, Nath N, Smith B, Viollet B, Singh AK \& Singh I 2004 5-Aminoimidazole-4-carboxamide-1-beta-4-ribofuranoside inhibits proinflammatory response in glial cells: a possible role of AMPactivated protein kinase. Journal of Neuroscience 24 479-487. (https:// doi.org/10.1523/JNEUROSCI.4288-03.2004)

Göbl CS, Bozkurt L, Yarragudi R, Prikoszovich T, Tura A, Pacini G, Koppensteiner R \& Kautzky-Willer A 2014 Biomarkers of endothelial dysfunction in relation to impaired carbohydrate metabolism following pregnancy with gestational diabetes mellitus. Cardiovascular Diabetology 13 138. (https://doi.org/10.1186/s12933014-0138-3)

Gregor MF \& Hotamisligil GS 2011 Inflammatory mechanisms in obesity. Annual Review of Immunology 29 415-445. (https://doi. org/10.1146/annurev-immunol-031210-101322)

Grimes CA \& Jope RS 2001 The multifaceted roles of glycogen synthase kinase 3beta in cellular signaling. Progress in Neurobiology $65391-$ 426. (https://doi.org/10.1016/S0301-0082(01)00011-9)

Gui J, Potthast A, Rohrbach A, Borns K, Das AM \& Von Versen-Hoynck F 2016 Gestational diabetes induces alterations of sirtuins in fetal 
endothelial cells. Pediatric Research 79 788-798. (https://doi. org/10.1038/pr.2015.269)

HAPO Study Cooperative Research Group, Metzger BE, Lowe LP, Dyer AR, Trimble ER, Chaovarindr U, Coustan DR, Hadden DR, McCance DR, Hod M, et al. 2008 Hyperglycemia and adverse pregnancy outcomes. New England Journal of Medicine 358 19912002. (https://doi.org/10.1056/NEJMoa0707943)

Hauguel-de Mouzon S \& Guerre-Millo M 2006 The placenta cytokine network and inflammatory signals. Placenta 27 794-798. (https://doi. org/10.1016/j.placenta.2005.08.009)

Hay WW 2006 Placental-fetal glucose exchange and fetal glucose metabolism. Transactions of the American Clinical and Climatological Association 117 321-339; discussion 339-340.

Hayashi T, Hirshman MF, Kurth EJ, Winder WW \& Goodyear LJ 1998 Evidence for 5'AMP-activated protein kinase mediation of the effect of muscle contraction on glucose transport. Diabetes 47 1369-1373. (https://doi.org/10.2337/diab.47.8.1369)

Hedderson MM, Gunderson EP \& Ferrara A 2010 Gestational weight gain and risk of gestational diabetes mellitus. Obstetrics and Gynecology 115 597-604. (https://doi.org/10.1097/ AOG.0b013e3181cfce4f)

Heerwagen MJ, Miller MR, Barbour LA \& Friedman JE 2010 Maternal obesity and fetal metabolic programming: a fertile epigenetic soil. American Journal of Physiology: Regulatory, Integrative and Comparative Physiology 299 R711-R722. (https://doi.org/10.1152/ ajpregu.00310.2010)

Heim KR, Mulla MJ, Potter JA, Han CS, Guller S \& Abrahams VM 2018 Excess glucose induce trophoblast inflammation and limit cell migration through HMGB1 activation of toll-like receptor 4. American Journal of Reproductive Immunology 80 e13044. (https://doi. org/10.1111/aji.13044)

Herrera E 2000 Metabolic adaptations in pregnancy and their implications for the availability of substrates to the fetus. European Journal of Clinical Nutrition $\mathbf{5 4}$ S47-S51. (https://doi.org/10.1038/sj. ejcn.1600984)

Highman TJ, Friedman JE, Huston LP, Wong WW \& Catalano PM 1998 Longitudinal changes in maternal serum leptin concentrations, body composition, and resting metabolic rate in pregnancy. American Journal of Obstetrics and Gynecology 178 1010-1015. (https://doi. org/10.1016/s0002-9378(98)70540-x)

Hirschey MD, Shimazu T, Jing E, Grueter CA, Collins AM, Aouizerat B, Stancakova A, Goetzman E, Lam MM, Schwer B, et al. 2011 SIRT3 deficiency and mitochondrial protein hyperacetylation accelerate the development of the metabolic syndrome. Molecular Cell 44 177-190. (https://doi.org/10.1016/j.molcel.2011.07.019)

Hoeflich KP, Luo J, Rubie EA, Tsao MS, Jin O \& Woodgett JR 2000 Requirement for glycogen synthase kinase-3beta in cell survival and NF-kappaB activation. Nature 406 86-90. (https://doi. org/10.1038/35017574)

Holdsworth-Carson SJ, Lim R, Mitton A, Whitehead C, Rice GE, Permezel M \& Lappas M 2010 Peroxisome proliferator-activated receptors are altered in pathologies of the human placenta: gestational diabetes mellitus, intrauterine growth restriction and preeclampsia. Placenta 31 222-229. (https://doi.org/10.1016/j. placenta.2009.12.009)

Hotamisligil GS 2010 Endoplasmic reticulum stress and the inflammatory basis of metabolic disease. Cell 140 900-917. (https:// doi.org/10.1016/j.cell.2010.02.034)

Hu P, Han Z, Couvillon AD, Kaufman RJ \& Exton JH 2006 Autocrine tumor necrosis factor alpha links endoplasmic reticulum stress to the membrane death receptor pathway through IRE1 alpha-mediated NF-kappa B activation and down-regulation of TRAF2 expression. Molecular and Cellular Biology 26 3071-3084. (https://doi. org/10.1128/МСВ.26.8.3071-3084.2006)

Hubel CA, Shakir Y, Gallaher MJ, Mclaughlin MK \& Roberts JM 1998 Low-density lipoprotein particle size decreases during normal pregnancy in association with triglyceride increases. Journal of the Society for Gynecologic Investigation 5 244-250. (https://doi. org/10.1177/107155769800500504)

Hundal RS, Petersen KF, Mayerson AB, Randhawa PS, Inzucchi S, Shoelson SE \& Shulman GI 2002 Mechanism by which high-dose aspirin improves glucose metabolism in type 2 diabetes. Journal of Clinical Investigation 109 1321-1326. (https://doi.org/10.1172/ JCI14955)

Illsley NP 2000 Glucose transporters in the human placenta. Placenta 21 14-22. (https://doi.org/10.1053/plac.1999.0448)

Ishak M \& Petocz P 2003 Gestational diabetes among Aboriginal Australians: prevalence, time trend, and comparisons with nonAboriginal Australians. Ethnicity and Disease 13 55-60.

Jansson T \& Powell TL 2006. IFPA 2005 Award in Placentology Lecture. Human placental transport in altered fetal growth: does the placenta function as a nutrient sensor? A review. Placenta 27 S91-S97. (https://doi.org/10.1016/j.placenta.2005.11.010)

Jansson T, Wennergren M \& Illsley NP 1993 Glucose transporter protein expression in human placenta throughout gestation and in intrauterine growth retardation. Journal of Clinical Endocrinology and Metabolism 77 1554-1562. (https://doi.org/10.1210/ jcem.77.6.8263141)

Jansson T, Scholtbach V \& Powell TL 1998 Placental transport of leucine and lysine is reduced in intrauterine growth restriction. Pediatric Research 44 532-537. (https://doi.org/10.1203/00006450-19981000000011)

Jansson T, Ekstrand Y, Bjorn C, Wennergren M \& Powell TL 2002 Alterations in the activity of placental amino acid transporters in pregnancies complicated by diabetes. Diabetes 51 2214-2219. (https://doi.org/10.2337/diabetes.51.7.2214)

Jansson N, Greenwood SL, Johansson BR, Powell TL \& Jansson T 2003 Leptin stimulates the activity of the system A amino acid transporter in human placental villous fragments. Journal of Clinical Endocrinology and Metabolism 88 1205-1211. (https://doi. org/10.1210/jc.2002-021332)

Jansson N, Rosario FJ, Gaccioli F, Lager S, Jones HN, Roos S, Jansson T \& Powell TL 2013 Activation of placental mTOR signaling and amino acid transporters in obese women giving birth to large babies. Journal of Clinical Endocrinology and Metabolism 98 105-113. (https://doi. org/10.1210/jc.2012-2667)

Jawerbaum A, Capobianco E, Pustovrh C, White V, Baier M, Salzberg S, Pesaresi M \& Gonzalez E 2004 Influence of peroxisome proliferatoractivated receptor gamma activation by its endogenous ligand 15-deoxy Delta12,14 prostaglandin J2 on nitric oxide production in term placental tissues from diabetic women. Molecular Human Reproduction 10 671-676. (https://doi.org/10.1093/molehr/gah090)

Jing E, Emanuelli B, Hirschey MD, Boucher J, Lee KY, Lombard D, Verdin EM \& Kahn CR 2011 Sirtuin-3 (Sirt3) regulates skeletal muscle metabolism and insulin signaling via altered mitochondrial oxidation and reactive oxygen species production. PNAS 10814608 14613. (https://doi.org/10.1073/pnas.1111308108)

Jones HN, Powell TL \& Jansson T 2007 Regulation of placental nutrient transport - a review. Placenta 28 763-774. (https://doi.org/10.1016/j. placenta.2007.05.002)

Jope RS \& Johnson GV 2004 The glamour and gloom of glycogen synthase kinase-3. Trends in Biochemical Sciences 29 95-102. (https:// doi.org/10.1016/j.tibs.2003.12.004)

Jope RS, Yuskaitis CJ \& Beurel E 2007 Glycogen synthase kinase-3 (GSK3): inflammation, diseases, and therapeutics. Neurochemical Research 32 577-595. (https://doi.org/10.1007/s11064-006-9128-5)

Kalhan S \& Parimi P 2000 Gluconeogenesis in the fetus and neonate. Seminars in Perinatology 24 94-106. (https://doi.org/10.1053/ sp.2000.6360)

Kaneko M, Niinuma Y \& Nomura Y 2003 Activation signal of nuclear factor-kappa B in response to endoplasmic reticulum stress is transduced via IRE1 and tumor necrosis factor receptor-associated 
factor 2. Biological and Pharmaceutical Bulletin 26 931-935. (https:// doi.org/10.1248/bpb.26.931)

Karl PI 1995 Insulin-like growth factor-1 stimulates amino acid uptake by the cultured human placental trophoblast. Journal of Cellular Physiology 165 83-88. (https://doi.org/10.1002/jcp.1041650111)

Karl PI, Alpy KL \& Fisher SE 1992 Amino acid transport by the cultured human placental trophoblast: effect of insulin on AIB transport. American Journal of Physiology 262 C834-C839. (https://doi. org/10.1152/ajpcell.1992.262.4.C834)

Katerelos M, Mudge SJ, Stapleton D, Auwardt RB, Fraser SA, Chen CG, Kemp BE \& Power DA 2010 5-Aminoimidazole-4-carboxamide ribonucleoside and AMP-activated protein kinase inhibit signalling through NF-kappaB. Immunology and Cell Biology 88 754-760. (https://doi.org/10.1038/icb.2010.44)

Kautzky-Willer A, Pacini G, Tura A, Bieglmayer C, Schneider B, Ludvik B, Prager R \& Waldhausl W 2001 Increased plasma leptin in gestational diabetes. Diabetologia 44 164-172. (https://doi.org/10.1007/ s001250051595)

Kendrick AA, Choudhury M, Rahman SM, McCurdy CE, Friederich M, van Hove JL, Watson PA, Birdsey N, Bao J, Gius D, et al. 2011 Fatty liver is associated with reduced SIRT3 activity and mitochondrial protein hyperacetylation. Biochemical Journal 433 505-514. (https:// doi.org/10.1042/BJ20100791)

Kim JK, Kim YJ, Fillmore JJ, Chen Y, Moore I, Lee J, Yuan M, Li ZW, Karin M, Perret P, et al. 2001 Prevention of fat-induced insulin resistance by salicylate. Journal of Clinical Investigation 108 437-446. (https://doi.org/10.1172/JCI11559)

Kim C, Newton KM \& Knopp RH 2002 Gestational diabetes and the incidence of type 2 diabetes: a systematic review. Diabetes Care $\mathbf{2 5}$ 1862-1868. (https://doi.org/10.2337/diacare.25.10.1862)

Kim S, Joe Y, Jeong SO, Zheng M, Back SH, Park SW, Ryter SW \& Chung HT 2013a Endoplasmic reticulum stress is sufficient for the induction of IL- $1 \beta$ production via activation of the NF- $\mathrm{KB}$ and inflammasome pathways. Innate Immunity 20 799-815. (https://doi. org/10.1177/1753425913508593)

Kim SY, Sappenfield W, Sharma AJ, Wilson HG, Bish CL, Salihu HM \& England LJ 2013b Racial/ethnic differences in the prevalence of gestational diabetes mellitus and maternal overweight and obesity, by nativity, Florida, 2004-2007. Obesity 21 E33-E40. (https://doi. org/10.1002/oby.20025)

Kim SJ, Lim JY, Lee JN, Choe SK, Kim YI, Song SR, Cho M, So HS \& Park R 2014 Activation of beta-catenin by inhibitors of glycogen synthase kinase-3 ameliorates cisplatin-induced cytotoxicity and proinflammatory cytokine expression in HEI-OC1 cells. Toxicology $\mathbf{3 2 0}$ 74-82. (https://doi.org/10.1016/j.tox.2014.01.013)

Kirwan JP, Hauguel-De Mouzon S, Lepercq J, Challier JC, HustonPresley L, Friedman JE, Kalhan SC \& Catalano PM 2002 TNF-alpha is a predictor of insulin resistance in human pregnancy. Diabetes $\mathbf{5 1}$ 2207-2213. (https://doi.org/10.2337/diabetes.51.7.2207)

Kleiblova P, Dostalova I, Bartlova M, Lacinova Z, Ticha I, Krejci V, Springer D, Kleibl Z \& Haluzik M 2010 Expression of adipokines and estrogen receptors in adipose tissue and placenta of patients with gestational diabetes mellitus. Molecular and Cellular Endocrinology 314 150-156. (https://doi.org/10.1016/j.mce.2009.08.002)

Knabl J, Huttenbrenner R, Hutter S, Gunthner-Biller M, Vrekoussis T, Karl K, Friese K, Kainer F \& Jeschke U 2014 Peroxisome proliferatoractivated receptor-gamma (PPARgamma) is downregulated in trophoblast cells of gestational diabetes mellitus (GDM) and in trophoblast tumour cells BeWo in vitro after stimulation with PPARgamma agonists. Journal of Perinatal Medicine 42 179-187. (https://doi.org/10.1515/jpm-2013-0039)

Knock GA, McCarthy AL, Lowy C \& Poston L 1997 Association of gestational diabetes with abnormal maternal vascular endothelial function. British Journal of Obstetrics and Gynaecology 104 229-234. (https://doi.org/10.1111/j.1471-0528.1997.tb11051.x)
Koves TR, Ussher JR, Noland RC, Slentz D, Mosedale M, Ilkayeva O, Bain J, Stevens R, Dyck JR, Newgard CB, et al. 2008 Mitochondrial overload and incomplete fatty acid oxidation contribute to skeletal muscle insulin resistance. Cell Metabolism 7 45-56. (https://doi. org/10.1016/j.cmet.2007.10.013)

Kuzmicki M, Telejko B, Wawrusiewicz-Kurylonek N, Citko A, Lipinska D, Pliszka J, Wilk J, Kalejta K, Lemancewicz A, Grabiec M, et al. 2012 The expression of suppressor of cytokine signaling 1 and 3 in fat and placental tissue from women with gestational diabetes. Gynecological Endocrinology 28 841-844. (https://doi.org/10.3109/095 13590.2012.683055)

Kuzmicki M, Telejko B, Wawrusiewicz-Kurylonek N, Lipinska D, Pliszka J, Wilk J, Zielinska A, Skibicka J, Szamatowicz J, Kretowski A, et al. 2013 The expression of genes involved in NF-kappaB activation in peripheral blood mononuclear cells of patients with gestational diabetes. European Journal of Endocrinology 168 419-427. (https://doi. org/10.1530/EJE-12-0654)

Lain KY \& Catalano PM 2007 Metabolic changes in pregnancy. Clinical Obstetrics and Gynecology 50 938-948. (https://doi.org/10.1097/ GRF.0b013e31815a5494)

Lam KS, Li DF, Lauder IJ, Lee CP, Kung AW \& Ma JT 1991 Prediction of persistent carbohydrate intolerance in patients with gestational diabetes. Diabetes Research and Clinical Practice 12 181-186. (https:// doi.org/10.1016/0168-8227(91)90075-O)

Langer O, Yogev Y, Most O \& Xenakis EM 2005 Gestational diabetes: the consequences of not treating. American Journal of Obstetrics and Gynecology 192 989-997. (https://doi.org/10.1016/j.ajog.2004.11.039)

Laplante M \& Sabatini DM 2012 MTOR signaling in growth control and disease. Cell 149 274-293. (https://doi.org/10.1016/j. cell.2012.03.017)

Lappas M 2012 Anti-inflammatory properties of sirtuin 6 in human umbilical vein endothelial cells. Mediators of Inflammation 2012 597514. (https://doi.org/10.1155/2012/597514)

Lappas M 2014a Activation of inflammasomes in adipose tissue of women with gestational diabetes. Molecular and Cellular Endocrinology 382 74-83. (https://doi.org/10.1016/j.mce.2013.09.011)

Lappas M $2014 b$ Effect of pre-existing maternal obesity, gestational diabetes and adipokines on the expression of genes involved in lipid metabolism in adipose tissue. Metabolism: Clinical and Experimental 63 250-262. (https://doi.org/10.1016/j.metabol.2013.10.001)

Lappas M 2014c GSK3beta is increased in adipose tissue and skeletal muscle from women with gestational diabetes where it regulates the inflammatory response. PLOS ONE 9 e115854. (https://doi. org/10.1371/journal.pone.0115854)

Lappas M 2014d Markers of endothelial cell dysfunction are increased in human omental adipose tissue from women with pre-existing maternal obesity and gestational diabetes. Metabolism: Clinical and Experimental 63 860-873. (https://doi.org/10.1016/j. metabol.2014.03.007)

Lappas M, Permezel M \& Rice GE 2004 Release of proinflammatory cytokines and 8-isoprostane from placenta, adipose tissue, and skeletal muscle from normal pregnant women and women with gestational diabetes mellitus. Journal of Clinical Endocrinology and Metabolism 89 5627-5633. (https://doi.org/10.1210/jc.2003-032097)

Lappas M, Yee K, Permezel M \& Rice GE 2005a Release and regulation of leptin, resistin and adiponectin from human placenta, fetal membranes, and maternal adipose tissue and skeletal muscle from normal and gestational diabetes mellitus-complicated pregnancies. Journal of Endocrinology 186 457-465. (https://doi.org/10.1677/ joe.1.06227)

Lappas M, Yee K, Permezel M \& Rice GE 2005b Sulfasalazine and BAY 11-7082 interfere with the nuclear factor-kappa B and I kappa B kinase pathway to regulate the release of proinflammatory cytokines from human adipose tissue and skeletal muscle in vitro. Endocrinology 146 1491-1497. (https://doi.org/10.1210/en.2004-0809) (c) 2019 Society for Endocrinology Published by Bioscientifica Ltd. Printed in Great Britain 
Lappas M, Yee K, Permezel M \& Rice GE 2006 Lipopolysaccharide and TNF- $\alpha$ activate the nuclear factor kappa B pathway in the human placental JEG-3 cells. Placenta 27 568-575. (https://doi.org/10.1016/j. placenta.2005.06.003)

Lappas M, Hiden U, Desoye G, Froehlich J, Hauguel-De Mouzon S \& Jawerbaum A 2011a The role of oxidative stress in the pathophysiology of gestational diabetes mellitus. Antioxidants and Redox Signaling 15 3061-3100. (https://doi.org/10.1089/ ars.2010.3765)

Lappas M, Mitton A, Lim R, Barker G, Riley C \& Permezel M $2011 b$ SIRT1 is a novel regulator of key pathways of human labor. Biology of Reproduction 84 167-178. (https://doi.org/10.1095/ biolreprod.110.086983)

Lappas M, Andrikopoulos S \& Permezel M 2012 Hypoxanthine-xanthine oxidase down-regulates GLUT1 transcription via SIRT1 resulting in decreased glucose uptake in human placenta. Journal of Endocrinology 213 49-57. (https://doi.org/10.1530/JOE-11-0355)

Law KP \& Zhang H 2017 The pathogenesis and pathophysiology of gestational diabetes mellitus: deductions from a three-part longitudinal metabolomics study in China. Clinica Chimica Acta: International Journal of Clinical Chemistry 468 60-70. (https://doi. org/10.1016/j.cca.2017.02.008)

Lee AJ, Hiscock RJ, Wein P, Walker SP \& Permezel M 2007 Gestational diabetes mellitus: clinical predictors and long-term risk of developing type 2 diabetes: a retrospective cohort study using survival analysis. Diabetes Care 30 878-883. (https://doi.org/10.2337/dc06-1816)

Lekva T, Norwitz ER, Aukrust P \& Ueland T 2016 Impact of systemic inflammation on the progression of gestational diabetes mellitus. Current Diabetes Reports 16 26. (https://doi.org/10.1007/s11892-0160715-9)

Lendvai Á, Deutsch MJ, Plosch T \& Ensenauer R 2016 The peroxisome proliferator-activated receptors under epigenetic control in placental metabolism and fetal development. American Journal of Physiology: Endocrinology and Metabolism 310 E797-E810. (https://doi. org/10.1152/ajpendo.00372.2015)

Li L, Yang G, Shi S, Yang M, Liu H \& Boden G 2009 The adipose triglyceride lipase, adiponectin and visfatin are downregulated by tumor necrosis factor-alpha (TNF-alpha) in vivo. Cytokine 45 12-19. (https://doi.org/10.1016/j.cyto.2008.10.006)

Li Y, Cooper A, Odibo IN, Ahmed A, Murphy P, Koonce R, Dajani NK, Lowery CL, Roberts DJ, Maroteaux L, et al. 2016 Discrepancy in insulin regulation between gestational diabetes mellitus (GDM) platelets and placenta. Journal of Biological Chemistry 291 9657-9665 (https://doi.org/10.1074/jbc.M116.713693)

Lihn AS, Pedersen SB, Lund S \& Richelsen B 2008 The anti-diabetic AMPK activator AICAR reduces IL- 6 and IL- 8 in human adipose tissue and skeletal muscle cells. Molecular and Cellular Endocrinology 292 36-41. (https://doi.org/10.1016/j.mce.2008.06.004)

Liong S \& Lappas M 2015a Activation of AMPK improves inflammation and insulin resistance in adipose tissue and skeletal muscle from pregnant women. Journal of Physiology and Biochemistry 71 703-717. (https://doi.org/10.1007/s13105-015-0435-7)

Liong S \& Lappas M $2015 b$ Endoplasmic reticulum stress is increased in adipose tissue of women with gestational diabetes. PLOS ONE 10 e0122633. (https://doi.org/10.1371/journal.pone.0122633)

Liong S \& Lappas M 2016 Endoplasmic reticulum stress regulates inflammation and insulin resistance in skeletal muscle from pregnant women. Molecular and Cellular Endocrinology 425 11-25. (https://doi.org/10.1016/j.mce.2016.02.016)

Lo JC, Feigenbaum SL, Escobar GJ, Yang J, Crites YM \& Ferrara A 2006 Increased prevalence of gestational diabetes mellitus among women with diagnosed polycystic ovary syndrome: a population-based study. Diabetes Care 29 1915-1917. (https://doi.org/10.2337/dc060877)

Lombard DB, Alt FW, Cheng HL, Bunkenborg J, Streeper RS, Mostoslavsky R, Kim J, Yancopoulos G, Valenzuela D, Murphy A, et al. 2007 Mammalian Sir2 homolog SIRT3 regulates global mitochondrial lysine acetylation. Molecular and Cellular Biology 27 8807-8814. (https://doi.org/10.1128/MCB.01636-07)

Ma Q, Fan J, Wang J, Yang S, Cong Q, Wang R, Lv Q, Liu R \& Ning G 2015 High levels of chorionic gonadotrophin attenuate insulin sensitivity and promote inflammation in adipocytes. Journal of Molecular Endocrinology 54 161-170. (https://doi.org/10.1530/JME-140284)

Magarinos MP, Sanchez-Margalet V, Kotler M, Calvo JC \& Varone CL 2007 Leptin promotes cell proliferation and survival of trophoblastic cells. Biology of Reproduction 76 203-210. (https://doi.org/10.1095/ biolreprod.106.051391)

Magee TR, Ross MG, Wedekind L, Desai M, Kjos S \& Belkacemi L 2014 Gestational diabetes mellitus alters apoptotic and inflammatory gene expression of trophobasts from human term placenta. Journal of Diabetes and its Complications 28 448-459. (https://doi.org/10.1016/j. jdiacomp.2014.03.010)

Martin M, Rehani K, Jope RS \& Michalek SM 2005 Toll-like receptormediated cytokine production is differentially regulated by glycogen synthase kinase 3. Nature Immunology 6 777-784. (https://doi. org/10.1038/ni1221)

Martinon F, Chen X, Lee AH \& Glimcher LH 2010 TLR activation of the transcription factor XBP1 regulates innate immune responses in macrophages. Nature Immunology 11 411-418. (https://doi. $\operatorname{org} / 10.1038 /$ ni.1857)

McCarthy FP, Delany AC, Kenny LC \& Walsh SK 2013 PPAR-gamma - a possible drug target for complicated pregnancies. British Journal of Pharmacology 168 1074-1085. (https://doi.org/10.1111/bph.12069)

McGuckin MA, Eri RD, Das I, Lourie R \& Florin TH 2010 ER stress and the unfolded protein response in intestinal inflammation. American Journal of Physiology: Gastrointestinal and Liver Physiology 298 G820G832. (https://doi.org/10.1152/ajpgi.00063.2010)

Medzhitov R, Preston-Hurlburt P, Kopp E, Stadlen A, Chen CQ, Ghosh S \& Janeway CA 1998 MyD88 is an adaptor protein in the hToll/IL-1 receptor family signaling pathways. Molecular Cell 2 253-258. (https://doi.org/10.1016/S1097-2765(00)80136-7)

Mele J, Muralimanoharan S, Maloyan A \& Myatt L 2014 Impaired mitochondrial function in human placenta with increased maternal adiposity. American Journal of Physiology: Endocrinology and Metabolism 307 E419-E425. (https://doi.org/10.1152/ajpendo.00025.2014)

Metzger BE, Bybee DE, Freinkel N, Phelps RL, Radvany RM \& Vaisrub N 1985 Gestational diabetes mellitus: correlations between the phenotypic and genotypic characteristics of the mother and abnormal glucose tolerance during the first year postpartum. Diabetes 34 111-115. (https://doi.org/10.2337/diab.34.2.s111)

Michan S \& Sinclair D 2007 Sirtuins in mammals: insights into their biological function. Biochemical Journal 404 1-13. (https://doi. org/10.1042/BJ20070140)

Michishita E, Park JY, Burneskis JM, Barrett JC \& Horikawa I 2005 Evolutionarily conserved and nonconserved cellular localizations and functions of human SIRT proteins. Molecular Biology of the Cell 16 4623-4635. (https://doi.org/10.1091/mbc.e05-01-0033)

Mihaylova MM, Vasquez DS, Ravnskjaer K, Denechaud PD, Yu RT, Alvarez JG, Downes M, Evans RM, Montminy M \& Shaw RJ 2011 Class IIa histone deacetylases are hormone-activated regulators of FOXO and mammalian glucose homeostasis. Cell 145 607-621. (https://doi.org/10.1016/j.cell.2011.03.043)

Montonen J, Knekt P, Jarvinen R, Aromaa A \& Reunanen A 2003 Wholegrain and fiber intake and the incidence of type 2 diabetes. American Journal of Clinical Nutrition 77 622-629. (https://doi.org/10.1093/ ajcn/77.3.622)

Mordwinkin NM, Ouzounian JG, Yedigarova L, Montoro MN, Louie SG \& Rodgers KE 2013 Alteration of endothelial function markers in women with gestational diabetes and their fetuses. Journal of Maternal-Fetal and Neonatal Medicine 26 507-512. (https://doi.org/10. $3109 / 14767058.2012 .736564)$ 
Morino K, Neschen S, Bilz S, Sono S, Tsirigotis D, Reznick RM, Moore I, Nagai Y, Samuel V, Sebastian D, et al. 2008 Muscle-specific IRS-1 Ser$>$ Ala transgenic mice are protected from fat-induced insulin resistance in skeletal muscle. Diabetes 57 2644-2651. (https://doi. org/10.2337/db06-0454)

Motta MC, Divecha N, Lemieux M, Kamel C, Chen D, Gu W, Bultsma Y, Mcburney M \& Guarente L 2004 Mammalian SIRT1 represses forkhead transcription factors. Cell 116 551-563. (https://doi. org/10.1016/s0092-8674(04)00126-6)

Mrizak I, Arfa A, Fekih M, Debbabi H, Bouslema A, Boumaiza I, Zaouali M, Khan NA \& Tabka Z 2013 Inflammation and impaired endothelium-dependant vasodilatation in non obese women with gestational diabetes mellitus: preliminary results. Lipids in Health and Disease 12 93. (https://doi.org/10.1186/1476-511X-12-93)

Mrizak I, Grissa O, Henault B, Fekih M, Bouslema A, Boumaiza I, Zaouali M, Tabka Z \& Khan NA 2014 Placental infiltration of inflammatory markers in gestational diabetic women. General Physiology and Biophysics 33 169-176. (https://doi.org/10.4149/ gpb_2013075)

Muralimanoharan S, Maloyan A \& Myatt L 2016 Mitochondrial function and glucose metabolism in the placenta with gestational diabetes mellitus: role of miR-143. Clinical Science 130 931-941. (https://doi. org/10.1042/CS20160076)

Muzio M, Natoli G, Saccani S, Levrero M \& Mantovani A 1998 The human toll signaling pathway: divergence of nuclear factor kappaB and JNK/SAPK activation upstream of tumor necrosis factor receptorassociated factor 6 (TRAF6). Journal of Experimental Medicine 187 2097-2101. (https://doi.org/10.1084/jem.187.12.2097)

Nagaraju K, Raben N, Merritt G, Loeffler L, Kirk K \& Plotz P 1998 A variety of cytokines and immunologically relevant surface molecules are expressed by normal human skeletal muscle cells under proinflammatory stimuli. Clinical and Experimental Immunology 113 407-414. (https://doi.org/10.1046/j.1365-2249.1998.00664.x)

Nakagawa T, Zhu H, Morishima N, Li E, Xu J, Yankner BA \& Yuan J 2000 Caspase-12 mediates endoplasmic-reticulum-specific apoptosis and cytotoxicity by amyloid-beta. Nature $\mathbf{4 0 3} 98-103$. (https://doi. org/10.1038/47513)

Nikoulina SE, Ciaraldi TP, Mudaliar S, Mohideen P, Carter L \& Henry RR 2000 Potential role of glycogen synthase kinase- 3 in skeletal muscle insulin resistance of type 2 diabetes. Diabetes 49 263-271. (https:// doi.org/10.2337/diabetes.49.2.263)

Nishimura M \& Naito S 2005 Tissue-specific mRNA expression profiles of human toll-like receptors and related genes. Biological and Pharmaceutical Bulletin 28 886-892. (https://doi.org/10.1248/ bpb.28.886)

Norman RJ, Dewailly D, Legro RS \& Hickey TE 2007 Polycystic ovary syndrome. Lancet 370 685-697. (https://doi.org/10.1016/S01406736(07)61345-2)

Osmond DT, King RG, Brennecke SP \& Gude NM 2001 Placental glucose transport and utilisation is altered at term in insulin-treated, gestational-diabetic patients. Diabetologia 44 1133-1139. (https://doi. org/10.1007/s001250100609)

Ott R, Stupin JH, Melchior K, Schellong K, Ziska T, Dudenhausen JW, Henrich W, Rancourt RC \& Plagemann A 2018 Alterations of adiponectin gene expression and DNA methylation in adipose tissues and blood cells are associated with gestational diabetes and neonatal outcome. Clinical Epigenetics 10 131-131. (https://doi. org/10.1186/s13148-018-0567-z)

Ozcan U, Cao Q, Yilmaz E, Lee AH, Iwakoshi NN, Ozdelen E, Tuncman G, Gorgun C, Glimcher LH \& Hotamisligil GS 2004 Endoplasmic reticulum stress links obesity, insulin action, and type 2 diabetes. Science 306 457-461. (https://doi.org/10.1126/ science.1103160)

Ozcan U, Yilmaz E, Ozcan L, Furuhashi M, Vaillancourt E, Smith RO, Gorgun CZ \& Hotamisligil GS 2006 Chemical chaperones reduce ER stress and restore glucose homeostasis in a mouse model of type 2 diabetes. Science 313 1137-1140. (https://doi.org/10.1126/ science.1128294)

Palacín M, Lasunción MA, Martín A \& Herrera E 1985 Decreased uterine blood flow in the diabetic pregnant rat does not modify the augmented glucose transfer to the fetus. Neonatology 48 197-203. (https://doi.org/10.1159/000242172)

Patni S, Wynen LP, Seager AL, Morgan G, White JO \& Thornton CA 2009 Expression and activity of toll-like receptors 1-9 in the human term placenta and changes associated with labor at term. Biology of Reproduction 80 243-248. (https://doi.org/10.1095/ biolreprod.108.069252)

Perez-Perez A, Maymo J, Duenas JL, Goberna R, Calvo JC, Varone C \& Sanchez-Margalet V 2008 Leptin prevents apoptosis of trophoblastic cells by activation of MAPK pathway. Archives of Biochemistry and Biophysics 477 390-395. (https://doi.org/10.1016/j.abb.2008.06.015)

Perez-Perez A, Maymo J, Gambino Y, Guadix P, Duenas JL, Varone C \& Sanchez-Margalet V 2013 Insulin enhances leptin expression in human trophoblastic cells. Biology of Reproduction 89 20. (https://doi. org/10.1095/biolreprod.113.109348)

Perrin MC, Terry MB, Kleinhaus K, Deutsch L, Yanetz R, Tiram E, Calderon R, Friedlander Y, Paltiel O \& Harlap S 2007 Gestational diabetes as a risk factor for pancreatic cancer: a prospective cohort study. BMC Medicine 5 25. (https://doi.org/10.1186/17417015-5-25)

Perrin MC, Terry MB, Kleinhaus K, Deutsch L, Yanetz R, Tiram E, Calderon-Margalit R, Friedlander Y, Paltiel O \& Harlap S 2008 Gestational diabetes and the risk of breast cancer among women in the Jerusalem Perinatal Study. Breast Cancer Research and Treatment 108 129-135. (https://doi.org/10.1007/s10549-007-9585-9)

Pessin JE \& Saltiel AR 2000 Signaling pathways in insulin action: molecular targets of insulin resistance. Journal of Clinical Investigation 106 165-169. (https://doi.org/10.1172/JCI10582)

Philipps AF, Holzman IR, Teng C \& Battaglia FC 1978 Tissue concentrations of free amino acids in term human placentas. American Journal of Obstetrics and Gynecology 131 881-887. (https:// doi.org/10.1016/s0002-9378(16)33136-2)

Picard F, Wanatabe M, Schoonjans K, Lydon J, O'Malley BW \& Auwerx J 2002 Progesterone receptor knockout mice have an improved glucose homeostasis secondary to $\beta$-cell proliferation. PNAS 99 15644-15648. (https://doi.org/10.1073/pnas.202612199)

Populo H, Lopes JM \& Soares P 2012 The mTOR signalling pathway in human cancer. International Journal of Molecular Sciences 13 18861918. (https://doi.org/10.3390/ijms13021886)

Purohit JS, Hu P, Burke SJ, Collier JJ, Chen JG \& Zhao L 2013 The effects of NOD activation on adipocyte differentiation. Obesity 21 737-747. (https://doi.org/10.1002/oby.20275)

Purushotham A, Schug TT, Xu Q, Surapureddi S, Guo X \& Li X 2009 Hepatocyte-specific deletion of SIRT1 alters fatty acid metabolism and results in hepatic steatosis and inflammation. Cell Metabolism 9 327-338. (https://doi.org/10.1016/j.cmet.2009.02.006)

Qiu X, Brown K, Hirschey MD, Verdin E \& Chen D 2010 Calorie restriction reduces oxidative stress by SIRT3-mediated SOD2 activation. Cell Metabolism 12 662-667. (https://doi.org/10.1016/j. cmet.2010.11.015)

Radaelli T, Varastehpour A, Catalano P \& Hauguel-de Mouzon S 2003 Gestational diabetes induces placental genes for chronic stress and inflammatory pathways. Diabetes 52 2951-2958. (https://doi. $\operatorname{org} / 10.2337 /$ diabetes.52.12.2951)

Radaelli T, Lepercq J, Varastehpour A, Basu S, Catalano PM \& Hauguel-de Mouzon S 2009 Differential regulation of genes for fetoplacental lipid pathways in pregnancy with gestational and type 1 diabetes mellitus. American Journal of Obstetrics and Gynecology 201 209.e1-209.e10. (https://doi.org/10.1016/j.ajog.2009.04.019)

Rains JL \& Jain SK 2011 Oxidative stress, insulin signaling, and diabetes. Free Radical Biology and Medicine 50 567-575. (https://doi. org/10.1016/j.freeradbiomed.2010.12.006) 
Rajendrasozhan S, Yang SR, Kinnula VL \& Rahman I 2008 SIRT1, an antiinflammatory and antiaging protein, is decreased in lungs of patients with chronic obstructive pulmonary disease. American Journal of Respiratory and Critical Care Medicine 177 861-870. (https:// doi.org/10.1164/rccm.200708-12690C)

Ramsay JE, Ferrell WR, Crawford L, Wallace AM, Greer IA \& Sattar N 2002 Maternal obesity is associated with dysregulation of metabolic, vascular, and inflammatory pathways. Journal of Clinical Endocrinology and Metabolism 87 4231-4237. (https://doi. org/10.1210/jc.2002-020311)

Rayasam GV, Tulasi VK, Sodhi R, Davis JA \& Ray A 2009 Glycogen synthase kinase 3: more than a namesake. British Journal of Pharmacology 156 885-898. (https://doi. org/10.1111/j.1476-5381.2008.00085.x)

Reece EA, Leguizamon G \& Wiznitzer A 2009 Gestational diabetes: the need for a common ground. Lancet 373 1789-1797. (https://doi. org/10.1016/S0140-6736(09)60515-8)

Rieusset J, Bouzakri K, Chevillotte E, Ricard N, Jacquet D, Bastard JP, Laville M \& Vidal H 2004 Suppressor of cytokine signaling 3 expression and insulin resistance in skeletal muscle of obese and type 2 diabetic patients. Diabetes 53 2232-2241. (https://doi. org/10.2337/diabetes.53.9.2232)

Ring DB, Johnson KW, Henriksen EJ, Nuss JM, Goff D, Kinnick TR, Ma ST, Reeder JW, Samuels I, Slabiak T, et al. 2003 Selective glycogen synthase kinase 3 inhibitors potentiate insulin activation of glucose transport and utilization in vitro and in vivo. Diabetes 52 588-595. (https://doi.org/10.2337/diabetes.52.3.588)

Roberts VH, Pound LD, Thorn SR, Gillingham MB, Thornburg KL, Friedman JE, Frias AE \& Grove KL 2014 Beneficial and cautionary outcomes of resveratrol supplementation in pregnant nonhuman primates. FASEB Journal 28 2466-2477. (https://doi.org/10.1096/fj.13245472)

Rojas-Rodriguez R, Lifshitz LM, Bellve KD, Min SY, Pires J, Leung K, Boeras C, Sert A, Draper JT, Corvera S, et al. 2015 Human adipose tissue expansion in pregnancy is impaired in gestational diabetes mellitus. Diabetologia 58 2106-2114. (https://doi.org/10.1007/ s00125-015-3662-0)

Roos S, Jansson N, Palmberg I, Saljo K, Powell TL \& Jansson T 2007 Mammalian target of rapamycin in the human placenta regulates leucine transport and is down-regulated in restricted fetal growth. Journal of Physiology 582 449-459. (https://doi.org/10.1113/ jphysiol.2007.129676)

Roos S, Kanai Y, Prasad PD, Powell TL \& Jansson T 2009 Regulation of placental amino acid transporter activity by mammalian target of rapamycin. American Journal of Physiology: Cell Physiology 296 C142C150. (https://doi.org/10.1152/ajpcell.00330.2008)

Ruiz-Palacios M, Ruiz-Alcaraz AJ, Sanchez-Campillo M \& Larque E 2017 Role of insulin in placental transport of nutrients in gestational diabetes mellitus. Annals of Nutrition and Metabolism 70 16-25. (https://doi.org/10.1159/000455904)

Ryan EA, O'Sullivan MJ \& Skyler JS 1985 Insulin action during pregnancy: studies with the euglycemic clamp technique. Diabetes 34 380-389. (https://doi.org/10.2337/diab.34.4.380)

Salminen A, Hyttinen JM \& Kaarniranta K 2011 AMP-activated protein kinase inhibits NF-kappaB signaling and inflammation: impact on healthspan and lifespan. Journal of Molecular Medicine 89 667-676. (https://doi.org/10.1007/s00109-011-0748-0)

Sanders TH, Mcmichael RW. \& Hendrix KW 2000 Occurrence of resveratrol in edible peanuts. Journal of Agricultural and Food Chemistry 48 1243-1246. (https://doi.org/10.1021/jf990737b)

Sati L, Soygur B \& Celik-Ozenci C 2016 Expression of mammalian target of rapamycin and downstream targets in normal and gestational diabetic human term placenta. Reproductive Sciences 23 324-332. (https://doi.org/10.1177/1933719115602765)

Sattar N, Greer IA, Louden J, Lindsay G, Mcconnell M, Shepherd J \& Packard CJ 1997 Lipoprotein subfraction changes in normal pregnancy: threshold effect of plasma triglyceride on appearance of small, dense low density lipoprotein. Journal of Clinical Endocrinology and Metabolism 82 2483-2491. (https://doi.org/10.1210/ jcem.82.8.4126)

Saxena BN, Emerson K. \& Selenkow HA 1969 Serum placental lactogen (HPL) levels as an index of placental function. New England Journal of Medicine 281 225-231. (https://doi.org/10.1056/

NEJM196907312810501)

Segura MT, Demmelmair H, Krauss-Etschmann S, Nathan P, Dehmel S, Padilla MC, Rueda R, Koletzko B \& Campoy C 2017 Maternal BMI and gestational diabetes alter placental lipid transporters and fatty acid composition. Placenta 57 144-151. (https://doi.org/10.1016/j. placenta.2017.07.001)

Selenkow HA, Varma K, Younger D, White P \& Emerson K 1971 Patterns of serum immunoreactive human placental lactogen (IR-HPL) and chorionic gonadotropin (IR-HCG) in diabetic pregnancy. Diabetes 20 696-706. (https://doi.org/10.2337/diab.20.10.696)

Setji TL, Brown AJ \& Feinglos MN 2005 Gestational diabetes mellitus. Clinical Diabetes 23 17-24. (https://doi.org/10.2337/diaclin.23.1.17)

Shao J, Yamashita H, Qiao L, Draznin B \& Friedman JE 2002 Phosphatidylinositol 3-kinase redistribution is associated with skeletal muscle insulin resistance in gestational diabetes mellitus. Diabetes 51 19-29. (https://doi.org/10.2337/diabetes.51.1.19)

Silliman K, Shore V \& Forte TM 1994 Hypertriglyceridemia during late pregnancy is associated with the formation of small dense lowdensity lipoproteins and the presence of large buoyant high-density lipoproteins. Metabolism: Clinical and Experimental 43 1035-1041. (https://doi.org/10.1016/0026-0495(94)90186-4)

Singer W 1970 Human placental lactogen. Lancet 1 237. (https://doi. org/10.1016/S0140-6736(70)90588-X)

Sivan E, Chen X, Homko CJ, Reece EA \& Boden G 1997 Longitudinal study of carbohydrate metabolism in healthy obese pregnant women. Diabetes Care 20 1470-1475. (https://doi.org/10.2337/ diacare.20.9.1470)

Solomon CG, Willett WC, Carey VJ, Rich-Edwards J, Hunter DJ, Colditz GA, Stampfer MJ, Speizer FE, Spiegelman D \& Manson JE 1997 A prospective study of pregravid determinants of gestational diabetes mellitus. JAMA 278 1078-1083. (https://doi.org/10.1001/ jama.1997.03550130052036)

Spellacy WN, Teoh ES, Buhi WC, Birk SA \& Mccreary SA 1971 Value of human chorionic somatomammotropin in managing high-risk pregnancies. American Journal of Obstetrics and Gynecology 109 588598. (https://doi.org/10.1016/0002-9378(71)90634-x)

Sriwijitkamol A, Coletta DK, Wajcberg E, Balbontin GB, Reyna SM, Barrientes J, Eagan PA, Jenkinson CP, Cersosimo E, Defronzo RA, et al. 2007 Effect of acute exercise on AMPK signaling in skeletal muscle of subjects with type 2 diabetes - a time-course and doseresponse study. Diabetes 56 836-848. (https://doi.org/10.2337/db061119)

Strakovsky RS \& Pan YX 2012 In utero oxidative stress epigenetically programs antioxidant defense capacity and adulthood diseases. Antioxidants and Redox Signaling 17 237-253. (https://doi. org/10.1089/ars.2011.4372)

Strober W, Murray PJ, Kitani A \& Watanabe T 2006 Signalling pathways and molecular interactions of NOD1 and NOD2. Nature Reviews: Immunology 6 9-20. (https://doi.org/10.1038/nri1747)

Suntorn R \& Panichkul P 2015 Prevalence of gestational diabetes mellitus detected by International Association of the Diabetes and Pregnancy study groups (IADPSG) criteria in Phramongkutklao Hospital. Thai Journal of Obstetrics and Gynaecology 23 144-150. (https://doi.org/10.14456/tjog.2015.24)

Suranyi A, Kozinszky Z, Molnar A, Nyari T, Bito T \& Pal A 2013 Placental three-dimensional power Doppler indices in midpregnancy and late pregnancy complicated by gestational diabetes mellitus. Prenatal Diagnosis 33 952-958. (https://doi.org/10.1002/ pd.4172) 
Tangeras LH, Stodle GS, Olsen GD, Leknes AH, Gundersen AS, Skei B, Vikdal AJ, Ryan L, Steinkjer B, Myklebost MF, et al. 2014 Functional toll-like receptors in primary first-trimester trophoblasts. Journal of Reproductive Immunology 106 89-99. (https://doi.org/10.1016/j. jri.2014.04.004)

Tao R, Coleman MC, Pennington JD, Ozden O, Park SH, Jiang H, Kim HS, Flynn CR, Hill S, Hayes Mcdonald W, et al. 2010 Sirt3mediated deacetylation of evolutionarily conserved lysine 122 regulates MnSOD activity in response to stress. Molecular Cell $\mathbf{4 0}$ 893-904. (https://doi.org/10.1016/j.molcel.2010.12.013)

Taricco E, Radaelli T, Nobile de Santis MS \& Cetin I 2003 Foetal and placental weights in relation to maternal characteristics in gestational diabetes. Placenta 24 343-347. (https://doi.org/10.1053/ plac.2002.0913)

Tong GX, Cheng J, Chai J, Geng QQ, Chen PL, Shen XR, Liang H \& Wang DB 2014 Association between gestational diabetes mellitus and subsequent risk of cancer: a systematic review of epidemiological studies. Asian Pacific Journal of Cancer Prevention 15 4265-4269. (https://doi.org/10.7314/apjcp.2014.15.10.4265)

Tran HT, Liong S, Lim R, Barker G \& Lappas M 2017 Resveratrol ameliorates the chemical and microbial induction of inflammation and insulin resistance in human placenta, adipose tissue and skeletal muscle. PLOS ONE 12 e0173373. (https://doi.org/10.1371/journal. pone.0173373)

Tsiotra PC, Halvatsiotis P, Patsouras K, Maratou E, Salamalekis G, Raptis SA, Dimitriadis G \& Boutati E 2018 Circulating adipokines and mRNA expression in adipose tissue and the placenta in women with gestational diabetes mellitus. Peptides 101 157-166. (https://doi. org/10.1016/j.peptides.2018.01.005)

Ueland T, Michelsen AE, Aukrust P, Henriksen T, Bollerslev J \& Lekva T 2019 Adipokines and macrophage markers during pregnancypossible role for $\mathrm{SCD} 163$ in prediction and progression of gestational diabetes mellitus. Diabetes/Metabolism Research and Reviews 35 e3114. (https://doi.org/10.1002/dmrr.3114)

Uysal KT, Wiesbrock SM, Marino MW \& Hotamisligil GS 1997 Protection from obesity-induced insulin resistance in mice lacking TNF-alpha function. Nature 389 610-614. (https://doi.org/10.1038/39335)

Uysal KT, Wiesbrock SM \& Hotamisligil GS 1998 Functional analysis of tumor necrosis factor (TNF) receptors in TNF-alpha-mediated insulin resistance in genetic obesity. Endocrinology 139 4832-4838. (https:// doi.org/10.1210/endo.139.12.6337)

Vasselon T \& Detmers PA 2002 Toll receptors: a central element in innate immune responses. Infection and Immunity 70 1033-1041. (https://doi.org/10.1128/iai.70.3.1033-1041.2002)

Verfaillie T, Garg AD \& Agostinis P 2013 Targeting ER stress induced apoptosis and inflammation in cancer. Cancer Letters 332 249-264. (https://doi.org/10.1016/j.canlet.2010.07.016)

Vrachnis N, Belitsos P, Sifakis S, Dafopoulos K, Siristatidis C, Pappa KI \& Iliodromiti Z 2012 Role of adipokines and other inflammatory mediators in gestational diabetes mellitus and previous gestational diabetes mellitus. International Journal of Endocrinology 2012549748. (https://doi.org/10.1155/2012/549748)

Wada T, Hori S, Sugiyama M, Fujisawa E, Nakano T, Tsuneki H, Nagira K, Saito S \& Sasaoka T 2010 Progesterone inhibits glucose uptake by affecting diverse steps of insulin signaling in 3T3-L1 adipocytes. American Journal of Physiology: Endocrinology and Metabolism 298 E881-E888. (https://doi.org/10.1152/ajpendo.00649.2009)

Wang H, Brown J \& Martin M 2011 Glycogen synthase kinase 3: a point of convergence for the host inflammatory response. Cytokine $\mathbf{5 3}$ 130-140. (https://doi.org/10.1016/j.cyto.2010.10.009)

Weissgerber TL, Wolfe LA, Davies GA \& Mottola MF 2006 Exercise in the prevention and treatment of maternal-fetal disease: a review of the literature. Applied Physiology, Nutrition, and Metabolism 31 661-674. (https://doi.org/10.1139/h06-060)

Westermeier F, Puebla C, Vega JL, Farias M, Escudero C, Casanello P \& Sobrevia L 2009 Equilibrative nucleoside transporters in fetal endothelial dysfunction in diabetes mellitus and hyperglycaemia. Current Vascular Pharmacology 7 435-449. (https://doi. org/10.2174/157016109789043900)

Winzer C, Wagner O, Festa A, Schneider B, Roden M, BancherTodesca D, Pacini G, Funahashi T \& Kautzky-Willer A 2004 Plasma adiponectin, insulin sensitivity, and subclinical inflammation in women with prior gestational diabetes mellitus. Diabetes Care $\mathbf{2 7}$ 1721-1727. (https://doi.org/10.2337/diacare.27.7.1721)

Wojcik M, Mac-Marcjanek K, Wozniak LA, Nadel I, Lewinski A \& Cypryk K 2014 The association of leukocyte phosphatidylinositol 3-kinase delta overexpression with gestational diabetes mellitus (GDM). Endokrynologia Polska 65 17-24. (https://doi.org/10.5603/ EP.2014.0003)

Wójcik M, Mac-Marcjanek K, Nadel I, Woźniak L \& Cypryk K 2015 Gestational diabetes mellitus is associated with increased leukocyte peroxisome proliferator-activated receptor $\gamma$ expression. Archives of Medical Science 11 779-787. (https://doi.org/10.5114/ aoms.2015.47692)

Wolf M, Sauk J, Shah A, Vossen Smirnakis K, Jimenez-Kimble R, Ecker JL \& Thadhani R 2004 Inflammation and glucose intolerance: a prospective study of gestational diabetes mellitus. Diabetes Care $\mathbf{2 7}$ 21-27. (https://doi.org/10.2337/diacare.27.1.21)

Woodgett JR 1990 Molecular cloning and expression of glycogen synthase kinase-3/factor A. EMBO Journal 9 2431-2438. (https://doi. org/10.1002/j.1460-2075.1990.tb07419.x)

Wu CS, Nohr EA, Bech BH, Vestergaard M \& Olsen J 2012 Long-term health outcomes in children born to mothers with diabetes: a population-based cohort study. PLoS ONE 7 e36727. (https://doi. org/10.1371/journal.pone.0036727)

Wullschleger S, Loewith R \& Hall MN 2006 TOR signaling in growth and metabolism. Cell 124 471-484. (https://doi.org/10.1016/j. cell.2006.01.016)

Xiang AH, Peters RK, Trigo E, Kjos SL, Lee WP \& Buchanan TA 1999 Multiple metabolic defects during late pregnancy in women at high risk for type 2 diabetes. Diabetes $\mathbf{4 8} 848-854$. (https://doi. org/10.2337/diabetes.48.4.848)

Xie BG, Jin S \& Zhu WJ 2014 Expression of toll-like receptor 4 in maternal monocytes of patients with gestational diabetes mellitus. Experimental and Therapeutic Medicine 7 236-240. (https://doi. org/10.3892/etm.2013.1360)

Xiong X, Saunders LD, Wang FL \& Demianczuk NN 2001 Gestational diabetes mellitus: prevalence, risk factors, maternal and infant outcomes. International Journal of Gynaecology and Obstetrics 75221 228. (https://doi.org/10.1016/S0020-7292(01)00496-9)

Xu XJ, Gauthier MS, Hess DT, Apovian CM, Cacicedo JM, Gokce N, Farb M, Valentine RJ \& Ruderman NB 2012 Insulin sensitive and resistant obesity in humans: AMPK activity, oxidative stress, and depot-specific changes in gene expression in adipose tissue. Journal of Lipid Research 53 792-801. (https://doi.org/10.1194/jlr. P022905)

Yang XH, Haghiac M, Glazebrook P, Minium J, Catalano PM \& Mouzon SHD 2015 Saturated fatty acids enhance TLR4 immune pathways in human trophoblasts. Human Reproduction 302152 2159. (https://doi.org/10.1093/humrep/dev173)

Yao L, Wan J, Li H, Ding J, Wang Y, Wang X \& Li M 2015 Resveratrol relieves gestational diabetes mellitus in mice through activating AMPK. Reproductive Biology and Endocrinology 13 118. (https://doi. org/10.1186/s12958-015-0114-0)

Yi-Jun Z, Ai L, Yu-Ling S, Yan L \& Hui Y 2012 Nucleotide-binding oligomerization domain-1 ligand induces inflammation and attenuates glucose uptake in human adipocytes. Chinese Medical Sciences Journal 27 147-152. (https://doi.org/10.1016/S10019294(14)60047-X)

Yu J, Zhou Y, Gui J, Li AZ, Su XL \& Feng L 2013 Assessment of the number and function of macrophages in the placenta of gestational diabetes mellitus patients. Journal of Huazhong University of Science 
and Technology: Medical Sciences 33 725-729. (https://doi. org/10.1007/s11596-013-1187-7)

Yuan M, Konstantopoulos N, Lee J, Hansen L, Li ZW, Karin M \& Shoelson SE 2001 Reversal of obesity- and diet-induced insulin resistance with salicylates or targeted disruption of IKKbeta. Science 293 1673-1677. (https://doi.org/10.1126/science.1061620)

Yung HW, Alnaes-Katjavivi P, Jones CJ, El-Bacha T, Golic M, Staff AC \& Burton GJ 2016 Placental endoplasmic reticulum stress in gestational diabetes: the potential for therapeutic intervention with chemical chaperones and antioxidants. Diabetologia 59 2240-2250. (https:// doi.org/10.1007/s00125-016-4040-2)

Zhang C, Liu S, Solomon CG \& Hu FB $2006 a$ Dietary fiber intake, dietary glycemic load, and the risk for gestational diabetes mellitus. Diabetes Care 29 2223-2230. (https://doi.org/10.2337/ dc06-0266)

Zhang KZ, Shen XH, Wu J, Sakaki K, Saunders T, Rutkowski DT, Back SH \& Kaufman RJ $2006 b$ Endoplasmic reticulum stress activates cleavage of CREBH to induce a systemic inflammatory response. Cell $\mathbf{1 2 4}$ 587-599. (https://doi.org/10.1016/j.cell.2005.11.040)
Zhang LJ, Chen S, Wu P, Hu CS, Thorne RF, Luo CM, Hersey P \& Zhang XD 2009 Inhibition of MEK blocks GRP78 up-regulation and enhances apoptosis induced by ER stress in gastric cancer cells. Cancer Letters 274 40-46. (https://doi.org/10.1016/j. canlet.2008.08.030)

Zhao L, Hu P, Zhou Y, Purohit J \& Hwang D 2011a NOD1 activation induces proinflammatory gene expression and insulin resistance in 3T3-L1 adipocytes. American Journal of Physiology: Endocrinology and Metabolism 301 E587-E598. (https://doi.org/10.1152/ ajpendo.00709.2010)

Zhao YH, Wang DP, Zhang LL, Zhang F, Wang DM \& Zhang WY $2011 b$ Genomic expression profiles of blood and placenta reveal significant immune-related pathways and categories in Chinese women with gestational diabetes mellitus. Diabetic Medicine 28 237-246. (https:// doi.org/10.1111/j.1464-5491.2010.03140.x)

Zhou YJ, Zhou H, Li Y \& Song YL 2012 NOD1 activation induces innate immune responses and insulin resistance in human adipocytes. Diabetes and Metabolism 38 538-543. (https://doi.org/10.1016/j. diabet.2012.08.001)

Received in final form 4 August 2019

Accepted 15 August 2019

Accepted Preprint published online 15 August 2019
(C) 2019 Society for Endocrinology Published by Bioscientifica Ltd. Printed in Great Britain 